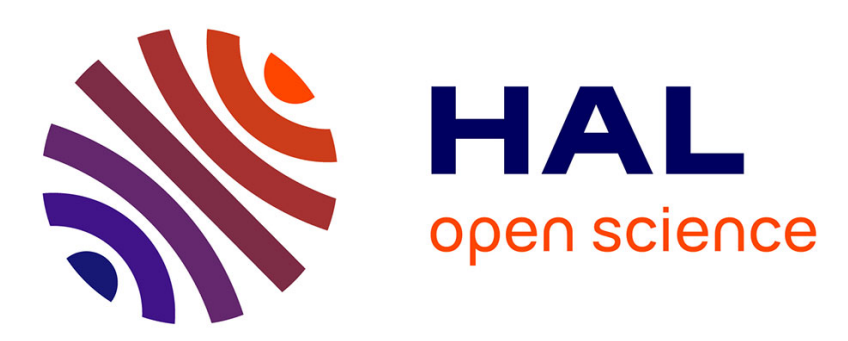

\title{
Responses of Collembola communities to mixtures of wheat varieties: a trait-based approach
}

Sandrine S. Salmon, Tom Vittier, Sébastien Barot, Jean-François Ponge, Farida Ben Assoula, Pauline Lusley

\section{- To cite this version:}

Sandrine S. Salmon, Tom Vittier, Sébastien Barot, Jean-François Ponge, Farida Ben Assoula, et al. Responses of Collembola communities to mixtures of wheat varieties: a trait-based approach. Pedobiologia, 2021, 87-88, pp.150755. 10.1016/j.pedobi.2021.150755 . hal-03315374

\author{
HAL Id: hal-03315374 \\ https://hal.science/hal-03315374
}

Submitted on 5 Aug 2021

HAL is a multi-disciplinary open access archive for the deposit and dissemination of scientific research documents, whether they are published or not. The documents may come from teaching and research institutions in France or abroad, or from public or private research centers.
L'archive ouverte pluridisciplinaire HAL, est destinée au dépôt et à la diffusion de documents scientifiques de niveau recherche, publiés ou non, émanant des établissements d'enseignement et de recherche français ou étrangers, des laboratoires publics ou privés. 
2 Responses of Collembola communities to mixtures of wheat varieties: a

3 trait-based approach

4 Sandrine Salmon ${ }^{\mathrm{a} 1}$, Tom Vittier ${ }^{\mathrm{a}}$, Sébastien Barot ${ }^{\mathrm{b}}$, Jean-François Ponge ${ }^{\mathrm{a}}$, Farida Ben

$5 \quad$ Assoula ${ }^{\mathrm{a}}$, Pauline Lusley ${ }^{\mathrm{c}, \mathrm{d}}$ and the Wheatamix consortium

$6 \quad$ a Muséum National d'Histoire Naturelle, Département Adaptations du Vivant, CNRS UMR

77179 MECADEV, 4 avenue du Petit Château, 91800 Brunoy, France

${ }^{\mathrm{b}}$ IEES-Paris (CNRS, UPMC, IRD, INRA, UPEC), UPMC, 4 place Jussieu, 75252 Paris Cedex

9

\section{ABSTRACT}

${ }^{1}$ Corresponding author.

E-mail address: sandrine.salmon@mnhn.fr (Sandrine Salmon) 
The genetic diversity of cultivated crops has decreased continuously since the beginning of the $20^{\text {th }}$ century, because of the gradual replacement of genetically heterogeneous traditional varieties by new genetically homogenous varieties, grown in monospecific stands. The resulting agro-ecosystems are now considered as unsustainable. Increasing within-field genetic crop diversity by using a mixture of varieties could increase the sustainability of these agro-ecosystems. This could also potentially increase non-crop biodiversity. In the present study we used an experimental approach to test whether the number of wheat varieties (genetic diversity), the number of functional groups (functional diversity), the composition of functional groups and wheat traits influence (1) species richness and abundance of Collembola, and (2) species and trait assemblages of Collembola. A total of 104 plots were seeded with either monocultures or mixtures of 2,4 and 8 wheat varieties. Soil cores were collected in each plot to extract Collembola and measure soil features. The number of wheat varieties and the functional wheat diversity did not influence the abundance and species richness of Collembola. The sensitivity of wheat to septoria leaf blotch was positively related to the abundance and species richness of Collembola, while specific root length was positively related to collembolan species richness. Wheat traits related to sensitivity to fungal diseases, (more especially septoria leaf blotch) and characteristics of aerial parts and roots impacted collembolan species and trait assemblages, but these effects were weak. Soil features, especially the proportion of coarse silt, were also influential. Our study did not show a favorable impact of wheat genetic diversity on soil Collembola, which might result from their low abundance. Nevertheless, it suggests correlations between some variety traits and the species richness and abundance of Collembola.

Keywords: crop management practices; genetic diversity; arthropod communities; wheat variety mixture; functional diversity; plant functional traits 


\section{Introduction}

Most current cropping systems are based on the use of a small number of species, usually grown in monospecific stands (Litrico et al., 2015). Within-field genetic diversity has decreased since the beginning of the $20^{\text {th }}$ century through the gradual replacement of genetically-heterogeneous traditional varieties with genetically-homogeneous varieties, often selected for higher yield or higher resistance to certain diseases (Bonnin et al., 2014). However, it is increasingly accepted that this mode of production is fragile and unsustainable: genetically poor farming systems can resist pests and maintain high yields only through the use of chemical inputs (e.g. nitrogen and phosphorus mineral fertilizers), and through the intensive use of pesticides that tend to decrease non-crop biodiversity (Tooker and Frank, 2012). A profound questioning of the modes of agricultural production thus became necessary. Favoring inter- and intraspecific crop diversity could be a promising alternative as part of sustainable agriculture (Barot et al., 2017a; Crutsinger et al., 2006; Loeuille et al., 2013).

Many studies showed that increasing plant species richness improved ecosystem functioning, e.g. increased nutrient retention or biomass production and stabilization of crop production (Prieto et al., 2015; Tooker and Frank, 2012). Plant diversity also increases the resistance of ecosystem productivity to climate extremes, which is an advantage in the context of global change (Isbell et al., 2015). Functional crop diversity (i.e. diversity of crop characteristics or traits) can even provide more ecosystem services than species richness per se, such as increases in yield or aboveground biomass nitrogen (Finney and Kaye, 2017). These favorable effects of biodiversity are partly explained by functional complementarity attributed to niche partitioning (Loreau and Hector, 2001). Another mechanism may explain the positive effect of crop diversity on ecosystem functions: the "sampling effect" (Barot et al., 2017a), i.e. the natural selection of species within a diverse community (compared to a 
community poorer in species), increases the likelihood of communities to host productive species in given local conditions (soil properties, climate...).. For instance, Prieto et al (2015) showed that multispecies assemblages of plants were more productive than monocultures when subjected to drought, and that the number of genotypes per species present increased the temporal stability of production under both drought and non-drought conditions. This led us to hypothesize that mixing crop varieties would lead to the same positive effects as increased species diversity, and through the same mechanisms (Barot et al., 2017b; Borg et al., 2018; Prieto et al., 2015).

Biodiversity in one trophic group may also impact biodiversity in other trophic groups through vertical, i.e. inter-trophic levels effects (Duffy et al., 2007). For example, the diversity of arthropods often increases with plant species richness (Castagneyrol and Jactel, 2012). Plant species richness and plant functional diversity have also often been shown to benefit growth, density and diversity of soil organisms (Eisenhauer et al., 2011; Milcu et al., 2006), presumably by improving quality or diversity of belowground resources. Nevertheless, a number of studies showed no strong, or controversial, effects of plant diversity per se on soil fauna (Wardle et al. 2003, Milcu et al. 2006, Korboulewsky et al. 2016), which highlights the lack of consistency in results so far obtained.

Intraspecific genetic diversity could lead to the same types of effect. For example the positive impact of plant genetic diversity (variety mixtures) on the diversity of arthropods has been shown in forests (Tovar-Sánchez et al., 2015) and agricultural crop systems (Crutsinger et al., 2006; McArt et al., 2012). It is hypothesized that, by increasing crop genetic and phenotypic diversity, the number of available resources increases, which in turn has a positive impact on the diversity of fauna (Abrams, 1983). Besides providing various food resources, mixtures of crop varieties could also provide different micro-habitats that can similarly shape richer arthropod communities. Moreover, experiments on variety mixtures have shown that 
intraspecific diversity can increase the abundance of natural enemies of insect pests and thus could be used as a plant disease management technique (Chateil et al., 2013; Zhu et al., 2000).

Collembola are an arthropod group known to be impacted by plant community composition and diversity (Chateil et al., 2013; Eisenhauer et al., 2011). They are among the most widespread and abundant groups of terrestrial arthropods and they impact ecosystem functioning by their high number (Hopkin, 1997). One of the main roles of Collembola is the regulation and dispersal of decomposer microorganisms (fungi and bacteria) which are responsible for the recycling of nutrients taken up by plants (de Vries et al., 2013). By consuming plant fungal pathogens, Collembola can limit fungal diseases (Meyer-Wolfarth et al., 2017; Schrader et al., 2013). By regulating the activity and dispersal of mycorrhizal fungi, they can also they can also either promote or reduce the uptake of nutrients by cultivated plants (Warnock et al., 1982; Ngosong et al., 2014) or regulate the architecture of some plants (Endlweber and Scheu, 2007).

A previous study showed that wheat genetic diversity benefited collembolan species richness in cultivated fields (Chateil et al., 2013). However, this study did not test for a possible effect of the identity/quality of varieties which could interact with the effect of genetic diversity. Other studies suggested that the quality of resources (e.g. litter) that enter belowground ecosystems, depending on plant identity, had more impact on the composition or biomass of soil fauna than plant diversity (Milcu et al., 2006; Viketoft and Sohlenius, 2011).

In the present study, we assessed whether the number of wheat varieties (genetic diversity), the number of functional groups (functional diversity), the composition of functional groups and wheat traits influence 1) the species richness and abundance of Collembola, and (2) species and trait assemblages of Collembola. The focus on functional traits of communities (e.g. plants), in addition to species, is an approach which allows 
addressing directly the functions fulfilled by organisms both at species and community levels (Vandewalle et al., 2010). Several studies showed that functional traits of Collembola allow better predicting environmental effects on soil collembolan communities than species do (Bokhorst et al., 2012; Salmon et al., 2014; Vanhee et al., 2017).

\section{Material and methods}

\subsection{Study site, wheat varieties and experimental design}

Our field experiment took place in an experimental research station in Versailles, France. Winter wheat Triticum aestivum was chosen because it is the main cereal crop of the region, and also because it displays a wide array of phenotypic variation among varieties. The experiment has been fully described in Dubs et al. (2018a).

We have followed the general approach of biodiversity-ecosystem functioning experiment as implemented in the Jena experiments (Weisser 2017) and thoughts on the implementation of functional diversity in such experiments (Ebeling 2014). Twenty-seven functional traits (above- and belowground morphological, phenological and physiological traits) have been measured in 57 varieties that have been chosen to be representative of the diversity of varieties cultivated in the Parisian basin. Hence they include both local landraces and modern elite varieties (Dubs et al., 2018a). Wheat traits were measured in the field and in greenhouses by different teams of the Wheatamix consortium in 2014 (i.e. before our experiment), except traits related to diseases that come from Arvalis and databases of two laboratories (see Table 2 of Dubs et al., 2018a ). Using a hierarchical clustering method (Ward method), these varieties have been classified on the base of 27 functional traits (yield, earliness, Specific Leaf Area, specific root length, root absorption capacity of nitrate and ammonium...) into 4 functional groups thereafter named c1, c2, c3, c4 clusters. Wheat varieties of the $\mathrm{c} 1$ functional group were characterized by high sensitivity to fungal diseases. 
143 Functional group c2 comprised wheat varieties with short root lengths, high rate of $\mathrm{NO}_{3}{ }^{-}$ 144 absorption, high relative growth rate and low sensitivity to fungal diseases. The c3 functional 145 group was composed of varieties characterized by their slow growth but elevated aggressiveness regarding plant-plant competition, and with high rate of $\mathrm{NH}_{4}^{+}$absorption capacity. Finally, the $\mathrm{c} 4$ functional group contained varieties with high specific root lengths, low relative growth rate and low rate of $\mathrm{NO}_{3}{ }^{-}$absorption capacity (Dubs et al. 2018a). Sixteen varieties have been selected to be used in the experiment, in order to maximize the overall functional diversity: for each cluster four varieties have been chosen avoiding varieties too far from the center of the cluster (thus varieties not representative of the cluster) and avoiding varieties that are too similar within the cluster. These 16 varieties were used to create 72 combinations of varieties encompassing three levels of diversity: 24, 28, and 20 mixtures combining 2, 4 and 8 varieties, respectively (Dubs et al., 2018a). The number of functional groups also varied in each of the three levels of variety mixtures: some mixtures were functionally "homogeneous" (a single functional group) while other were heterogeneous (two or more functional groups). Thus, these mixtures have been implemented for experimental purpose, to be able to compare mixtures with different number of varieties and different levels of functional diversity. These mixtures were clearly not designed because of their particular relevance for farmers. The list of varieties, mixtures and their distribution over the 104 plots are detailed in Dubs et al. (2018a). The 72 mixtures have been seeded into 72 plots and the 16 varieties have also been seeded alone, in duplicate, providing a total of $10410.5 \mathrm{~m} \mathrm{x} 8.0 \mathrm{~m}$ plots encompassing 4 levels of variety mixtures (1, 2, 4 and 8 varieties each).

Varieties were seeded in November 2014 after ploughing. After sowing, the mixtures of seeds from the different varieties we controlled for the spatial homogeneity of germination, which shows that all varieties germinated. The crop was grown with a target yield of 60 quintal ha ${ }^{-1}(75=$ French average national wheat yield in 2015). No insecticide and fungicide 
were used except for seed coating, the same for all varieties for which CELEST $\left(2 \mathrm{lt}^{-1}-\right.$ Fludioxonil $\left.25 \mathrm{~g} \mathrm{l}^{-1}\right)$ and SIGNAM $\left(0.6 \mathrm{~kg} \mathrm{~g} \mathrm{t}^{-1}\right.$-Cypermethryne $\left.300 \mathrm{~g} \mathrm{l}^{-1}\right)$ were used. One spraying of two herbicides (Archipel ${ }^{\circledR}, 50 \%$ Iodosulfuron and 50\% Mesosulfuron; Harmony Extra ${ }^{\circledR}, 66 \%$ thifensulfuron-methyl and 33\% tribenuron-methyle) was performed on March $14,2015.160 \mathrm{~kg} \mathrm{~N} \mathrm{ha}^{-1}$ was used as compared to the estimated optimal amount of $180 \mathrm{~kg} \mathrm{~N}$ $\mathrm{ha}^{-1}$. The fertilizer (ammonium-nitrate) was spread as follows: $40 \mathrm{~kg} \mathrm{~N} \mathrm{ha}^{-1}$ on March 5, 2015, $80 \mathrm{~kg} \mathrm{~N} \mathrm{ha}{ }^{-1}$ on April 16, 2015, $40 \mathrm{~kg} \mathrm{~N} \mathrm{ha}^{-1}$ on May 11, 2015. All plots were harvested between the last week of July and the first week of August 2015.

After harvest, wheat crop residues were left in the field until last soil faunal sampling (from which springtails were extracted), in November.

\subsection{Collembola sampling}

Collembola were sampled in March (one core sample taken in the center of each plot) and November 2015 (two core samples taken in the center of each half plot) in the 104 plots. The three samples taken in each plot at two sampling dates allowed better accounting spatial and temporal plot heterogeneity. Each core sample was $5 \mathrm{~cm}$ in diameter and $15 \mathrm{~cm}$ deep, leading to a total sampled area of $59 \mathrm{~cm}^{2}$ per plot. Collembola were extracted during ten days by the Berlese method (Edwards and Fletcher, 1971). The three samples of Collembola were pooled together for each plot because the density of Collembola in one sample was relatively low. They were then sorted, mounted, cleared in chloral-lactophenol and identified to species level under a light microscope (400× magnification) according to Hopkin (2007), Potapow (2001), Thibaud et al. (2004) and Bretfeld (1999). Other samples were taken in the same plots to measure soil features. A soil core $(5 \mathrm{~cm}$ diameter, $15 \mathrm{~cm}$ depth) was taken in the center of each plot to measure soil water content (dry/wet weight) and $\mathrm{pH}_{\text {water }}$ according to ISO 10390 in March 2015. Another soil core (8 cm diameter, $15 \mathrm{~cm}$ depth, litter excluded) was taken in 
the center of each plot in October 2015 to measure particle size distribution (clay, fine silt, coarse silt, fine sand, coarse sand) according to NF X 31-107, total concentration in nitrogen according to ISO 13878, total concentration in organic carbon and organic matter by dry combustion according to ISO 10694, and the C/N ratio. Soil analyses were performed at the INRA Laboratory for Soil Analysis (Arras, France).

\subsection{Statistical analysis}

Abundances of collembolan species in the three samples taken in each plot were pooled for the calculation of abundance and species richness per plot.

We performed generalized linear models (GLM) to determine whether the abundance and species richness of Collembola were influenced by the number of wheat varieties, wheat functional diversity (number of functional groups), functional group composition (c1, c2, c3, or c4) and mean of wheat functional traits in variety mixtures. Given the high number of wheat traits available, we first made an a priori selection according to their potential impact on Collembola. We selected traits related to root system, plant cover, and sensitivity to fungal diseases. At least some collembolan species are known to live and feed on roots (Thimm and Larink, 1995), depend on plant cover (Heiniger et al., 2015) and feed on fungi, including pathogenic fungi (Friberg et al., 2005; Jorgensen et al., 2005; Ponge, 1988). Wheat trait measures and soil features were then standardized (thus discarding spurious effects of various units). Spearman correlation coefficients were calculated between wheat traits, soil features and geographical coordinates in order to eliminate correlated explanatory variables (Table S3). As coarse silt was highly correlated with other particle size fractions and with geographical coordinates according to a textural gradient, the latter two sets of variables were discarded from further analyses. As the impact of soil texture on soil fauna is well known, especially in conventional agroecosystems (Grossi and Brun, 1997) we preferred to keep 
coarse silt and remove geographical coordinates. The set of soil features selected for further analyses was coarse silt, soil $\mathrm{pH}$, soil water content and $\mathrm{C} / \mathrm{N}$ ratio. Correlation coefficients also allowed to select the set of wheat traits used in further analyses (Table 1).

As the number of varieties and the number of functional groups bring redundant information about wheat diversity, they were analysed separately, like wheat traits and the composition of functional groups (groups of varieties associated according to their traits). We thus performed a first model to test the effect of wheat diversity (number of varieties), the composition of wheat functional groups (c1, c2, c3 and c4), and soil features, on species richness and abundance of Collembola, respectively. This model allowed to share the part of diversity and that of composition of functional groups (varying according to traits displayed in each functional group) in the effect of wheat on Collembola communities (Spehn et al. 2005). In the same way, we then analysed the effect of the number of functional groups (functional diversity), the set of wheat traits and soil features, on species richness and abundance of Collembola. Soil features were included in models, because the potential effect of variety mixtures on collembolan communities could be blurred or biased in the absence of reference to soil variation.

We then selected final models step by step, by keeping variables that significantly contributed to models and by using AIC (Spehn et al. 2005, Bolker et al. 2009). All models were diagnosed with the "DHARMa" package (Hartig, 2020) for R software: "Uniformity" (tests if the global distribution of residuals is in line with predicted values with a Kolmogorov-Smirnov test and a QQ-plot), "Outliers" (tests if there are more simulation outliers than expected), "Dispersion" (tests if the simulated dispersion is equal to the observed dispersion), "Quantiles" (fits a quantile regression or residuals against a predictor (predicted value by default), and tests if that predictor conforms to the expected quantile), 
"Zeroinflation" (tests if there are more zeros than expected). In order to fulfil all model assumptions (especially dispersion), collembolan abundances were log-transformed.

At last we performed Analyses of Deviance (Type II Wald chi-square tests) on final models, with the "Anova" function of the "car" R package. Full models and codes are detailed in Tables S3 to S7).

Canonical correspondence analysis (CCA; Ter Braak (1986) followed by Monte Carlo permutation tests (999 permutations) was used to assess whether wheat variety traits, variety number, functional group number, functional group composition and soil features constrained collembolan species assemblages. This technique was particularly appropriate to our data because it addresses the large number of zeros which characterizes community compositional data (Legendre and Legendre, 1998) and does not try to display all variation in the data, but only the part that can be explained by the constraints. Species represented by only one individual in one sample were deleted from CCA analyses. Two first CCAs were performed following the same logic and using the same explanatory variables as for GLM, i.e. one with the number of wheat varieties, the composition of wheat functional groups (c1, c2, c3, c4) and soil features (soil water content, $\mathrm{pH}_{\text {water }}$, coarse silt, and $\mathrm{C} / \mathrm{N}$ ratio), the other $\mathrm{CCA}$ with the number of wheat functional groups, wheat traits (see Table 1) and soil features. Soil features were included in all analyses to separate the variation of collembolan species distribution due to soil features from that due to wheat related variables. This also limited misinterpretations in the case of interactions between soil features and wheat related variables. Soil features and wheat traits were standardized prior to CCA. Then, partial CCAs (pCCA) were performed from each of the two first CCAs, to disentangle the effects of wheat diversity (number of variety or number of functional groups), wheat composition (functional group composition or traits) and soil features, on the composition of collembolan communities. Prior to partial 
using the same variables as for the two first CCAs, in order to classify explanatory variables according to their contribution to the distribution of species. Variables contributing most to species distribution (with the highest Variable Importance in the Projection, VIP) were included in three partial CCAs and their effect was displayed in three graphics (Figs. 3a, b, c).

Two redundancy analyses (RDA; Legendre and Legendre, 1998) were performed, following the same procedure and using the same explanatory variables as for GLM and CCA, to measure the effects of 1) variety number, functional group composition and soil features, and 2) functional group number, wheat variety traits (Table 1), and soil features, on community-weighted mean traits (CWM) of Collembola. RDA was chosen because CWMs are continuous variables. CWM traits have been widely used in ecological research for summarizing different facets of functional composition and shifts in mean trait values within communities due to environmental selection for some functional traits (Ricotta and Moretti, 2011). Collembolan traits were extracted from the Coltrait database (Salmon et al., 2014), then the CWM of each trait was calculated using "species $\mathrm{x}$ traits" and "plots $\mathrm{x}$ species abundance" matrices (Ricotta and Moretti, 2011). RDA is a direct gradient ordination method that constrains the position of response variables, here collembolan CWMs, by a set of environmental factors, here wheat related variables and soil features (Legendre and Legendre, 1998). Using RDA to analyze the impact of diverse environmental variables on the distribution of CWMs is a common practice in trait-based approaches in ecology (Vandewalle et al., 2010). As for pCCAs, partial RDAs (pRDA) were performed to disentangle the effects of wheat diversity (variety or functional group number), wheat composition (functional group composition or traits) and soil features on collembolan CWMs. Then, further partial RDAs were performed to assess the relative importance of traits related to either sensitivity to fungal diseases, crop canopy cover or root characteristics, after removing the effects of soil features, 
wheat diversity and of the two other types of wheat traits. RDAs were followed by Monte Carlo permutation tests (999 permutations).

GLMs were performed with R software (version 3.6.3, 2020), using the "glmmTMB" package (Brooks et al 2017) for GLM construction, the DHARMa package for diagnostics of models (Hartig, 2020). Analyses of Deviance on final models were performed with the "car" package (Fox, Weisberg, 2019). CWMs were calculated with the FD package (Laliberté et al., 2014) of R. CCA and RDA were performed with XLSTAT (v2013.3.05, Addinsoft, 2021).

\section{Results}

\subsection{Effect of wheat varieties on abundance and species richness of Collembola}

A total of 1,594 individuals were found. The abundance of Collembola in the three pooled samples varied from $10 \pm 0.53$ individuals $\left(1,698\right.$ ind. $\left.\mathrm{m}^{-2}\right)$ in plots with two varieties to $25 \pm 3.25$ individuals $\left(4,246\right.$ ind. $\left.\mathrm{m}^{-2}\right)$ in plots with eight varieties (mean \pm standard error), but the difference was not significant (Fig. 1a, Table S5). Collembolan species richness per plot did not vary with the number of wheat varieties, averaging four species per plot (Fig. 1b, Table S4). First, models showed that variety number and functional group number did not influence the species richness and abundance of Collembola (S4 and S5, Fig.1). Two wheat traits, Specific Root Length and sensitivity to septoria leaf blotch, and the c1 functional group positively increased the species richness of Collembola but to a lesser extent than the coarse silt content (Table 2, Figs. 2b, c, S2, S3b). The sensitivity to Septoria leaf blotch also significantly increased the abundance of Collembola but its effect was twice less than that of coarse silt content (Tables 2, S7, Figs. 2a, S3a). A negative effect of the c2 functional group 
on collembolan abundance was also detected by the first models but this effect was no longer significant (or only marginally significant) in the final model (Tables 2, S6).

\subsection{Effect of wheat varieties on species assemblages of Collembola}

The CCA with wheat variety number, wheat functional group composition (c1, c2, c3, c4) and soil features (soil water content, $\mathrm{pH}_{\text {water }}$, coarse silt, and $\mathrm{C} / \mathrm{N}$ ) showed that these variables significantly (p-value: 0.011 ) explained $23.3 \%$ of the variation of species distribution. Partial CCAs testing the effect of variety number and functional group composition after removing the effect of soil features showed that variety number and functional group composition significantly explained $9.4 \%$ (p-value: 0.010 ) of the collembolan species distribution. When variety number $(1.1 \%$, p-value 0.60$)$ and functional group composition (6.6\%, p-value: 0.13 ) were tested separately, their effect was not significant. The effect of soil features after removing the effect the variety number and functional group composition accounted for $8.7 \%$ (p-value: 0.006 ) of the collembolan species distribution.

The CCA with functional group number, wheat traits (Table 1) and soil features as explanatory variables showed that these variables significantly explained $27 \%$ (p-value: 0.04 ) of the variation of collembolan species distribution. Partial CCAs testing the effect of functional group number and wheat traits after removing the effect of soil features showed that functional group number and wheat traits significantly explained $14.5 \%$ (p-value: 0.01 ) of the collembolan species distribution. When the functional group number and wheat traits were tested separately, wheat traits significantly explained $13.1 \%$ (p-value 0.016 ) of collembolan species distribution, while the effect of functional group number was not significant $(1.173 \%$, 
p-value: 0.659). The effect of soil features after removing the effect of wheat traits and functional group number accounted for $10.8 \%$ (p-value $<0.0001)$.

The first CCA-PLS classified the variety number, functional group composition and soil features as follow: nbvar $>$ Co-silt $>$ C_N $>$ pH $>$ c2-0 $>$ c2-1 $>$ Water $>$ c3-0 $>$ c3-1 $>$ c1-0 $>$ c1-1 > c4-0>4-1. The second CCA-PLS classified functional group number, wheat traits and soil features as follows: GAIT1 > Co-silt > Septo $>$ pH > C_N > SRR > GAIT6 > nbclu $>$ YR $>$ Water $>$ SRL $>$ RD. In order to facilitate the interpretation of CCA graphs by limiting the effect of interacting factors, we performed three CCAs with the most influential variables given by the two CCA-PLSs: a first one with the number of wheat varieties and the c2 functional group (Fig. 3a), the second one with the three traits most contributing to Collembola species distribution (GAIT1, Septo, SRR, Fig. 3b) and the third CCA with the three most contributing soil features (Co-silt, pH, C/N, Fig. 3c). Figure 3a shows that species positively influenced by the number of wheat varieties were Proisotoma minuta, Seira domestica, Entomobrya lanuginosa and Folsomides parvulus. P. minima and Folsomia candida were more abundant in the c2 wheat functional group, while Desoria tigrina, Isotomurus palustris and Megalothorax gr. incertus were less abundant or absent from plots with the c2 functional group. Figure $3 b$ shows that D. tigrina, Seira domestica and Willowsia platani were positively influenced by plant cover (GAIT1). Isotomurus palustris, Sminthurinus elegans, Sminthurides signatus, Parisotoma notabilis and Megalothorax gr. incertus were positively impacted by the shoot/root ratio and/or the sensitivity to septoria. At last, Figure 3c shows that $F$. parvulus, $S$. signatus, Sminthurinus aureus, and P. minima were negatively impacted by coarse silt, contrary to P. minuta, F. candida, and Megalothorax minimus which were more frequent or abundant in plots with a higher level of coarse-silt. Higher soil $\mathrm{pH}$ was favorable to Heteromurus nitidus and I. palustris and the $\mathrm{C} / \mathrm{N}$ ratio positively influenced the distribution of $D$. trigrina and $S$. domestica. 


\subsection{Effect of wheat varieties on trait assemblages of Collembola}

The RDA testing the effect of wheat variety number, functional group composition and soil features showed that these variables together significantly explained $14.1 \%$ of the variation of collembolan trait distribution (p-value: 0.004). Partial RDAs testing the effect of variety number after removing the effects of soil features and functional group composition showed no significant effect on collembolan trait distribution $(0.45 \%$, p-value: 0.78$)$. The effect of functional group composition after removing that of soil features and variety number on collembolan trait distribution was not significant (5.1\%, p-value:0.17). Even when tested together after removing the effect of soil features, variety number and functional group composition had no significant effect. The effect of soil features after removing the effect the variety number and functional group composition accounted for 9.7\% (p-value:0.004) of the variation in collembolan trait distribution.

The RDA with wheat functional group number, wheat traits (Table 1) and soil features showed that these variables significantly explained $19.2 \%$ (p-value: 0.004 ) of the variation of collembolan trait distribution. Partial RDAs testing the effect of functional group number and wheat traits after removing the effect of soil features showed that they significantly explained 10.9\% (p-value: 0.004 ) of collembolan trait distribution. When functional group number and wheat traits were tested separately, wheat traits significantly explained $10.85 \%$ (p-value 0.015) of collembolan trait distribution, while the effect of functional group number was not significant $(0.08 \%$, p-value: 0.999$)$. The effect of soil features after removing the effect of wheat traits and functional group number accounted for $8.8 \%$ (p-value: 0.002) (Fig. 4a). Further partial RDAs were achieved to disentangle the effect of three types of wheat traits linked to: 1) roots (SRL, SRR, RD), 2) plant cover (Green Area Index: GAI), 3) sensitivity to fungal diseases (Septo, YR). These partial RDAs were performed after removing the effect of soil features, functional group number and the two other types of wheat traits than that tested. 
Traits linked to the root system (2.8\%, p-value: 0.45$)$ and plant cover (2.25\%, p-value: 0.29$)$ had no significant effects on the distribution of collembolan traits, respectively. The sensitivity to fungal diseases (septoriose and yellow rust) significantly explained $4.7 \%$ (pvalue: 0.018 ) of collembolan trait distribution (Fig. 4a).

Partial RDAs assessing the effects of the sensitivity to fungal diseases on the distribution of collembolan traits (Fig. 4a) showed that the sensitivity to septoria leaf blotch (Septo) was associated to Collembola with pigmented and spherical body, long furcula, presence of trichobothria, high ocelli number and living in superficial soil layers. Axis 2 separated collembolan traits according to sensitive and insensitive varieties to yellow rust. Collembola associated to the sensitivity to yellow rust were pigmented, with high ocelli number, pseudocelli, sexual reproduction and not specialized for a soil layer depth (NS).

The RDA assessing the effects of soil features (Fig.4b) (after removing variety number and functional group composition) showed that they explained 9.7\% ( $\mathrm{p}=0.004)$ of the variation in the distribution of collembolan traits. Axis 1 separated soils with a high content of coarse silt on the positive side from soils with a low content of coarse silt and thus more clay on the negative side. Axis 2 separated soils with a neutral $\mathrm{pH}$ from soils that were richer in organic matter $(\mathrm{C} / \mathrm{N})$ and wetter (Water). Plots with more coarse silt accommodated species living only deeply in the soil (Eda), or in upper soil layers (Hemieda), and species living in both deep and superficial soil layers (Eda-Hemieda) while soils with less coarse silt and thus more clay accommodated epigeic species, living above the soil surface (Epi) or species without preference regarding soil layers (NS). Morphological traits supported this interpretation: characteristics of epigeic species such as spherical body, higher number of visual organs (Ocel), long legs (LegL), long furcula (FurcaL), presence of trichobothria (Tricho) and pigmentation (Pigm) of the body were associated with soils displaying less coarse silt and therefore more clay. Species with cylindrical body occurred more frequently in 
soils with high coarse silt content. The number of Collembola that did not have a preference for soil depth (NS) was higher in average in wetter soils with a high $\mathrm{C} / \mathrm{N}$ ratio.

\section{Discussion}

\subsection{Effect of wheat varieties on the abundance and species richness of Collembola}

The number of wheat varieties and wheat functional groups (functional wheat diversity) did not impact the abundance and species richness of Collembola, contrary to our expectation (Hypothesis 1). This result is not due to the short duration of our study since Aström and Bengtsson (2011) observed no dispersal limitation of Collembola over distances as far as 3 meters in 10 weeks. Our results support the conclusions of several studies showing little effects of plant species or functional group richness on soil biota, including Collembola (Wardle et al. 2003, Salamon et al., 2004, Milcu et al. 2006, Korboulewsky et al. 2016). The weakness of the effect of wheat genetic diversity is supported by the results of Dubs et al. (2018b) for aboveground arthropods on the same experimental parcels. Nevertheless, plant genetic and functional diversities have been shown to increase the density and/ or the diversity of many groups of invertebrates (Crawford et al., 2007; Crutsinger et al., 2006; Johnson et al., 2006; Jones et al., 2011). Moreover, Chateil et al. (2013) observed that mixtures of wheat varieties increased the species richness of Collembola compared to a single wheat variety. However, in Chateil et al. (2013) the respective effects of diversity and composition of wheat varieties could not really be disentangled. In fact, the observed increase in collembolan species richness could have resulted from the identity of wheat varieties that had been added to the single variety (used as a control) when creating variety mixtures.

Discrepancies among the effects of plant diversity observed in different studies on species richness of Collembola suggest that these effects are weak and/or are blurred by interactive factors. The effect of crop diversity could depend on other factors such as 
agricultural practices (e.g. conventional vs. organic farming), surrounding landscape (Bengtsson et al., 2005; Jeanneret et al., 2003) and soil features (Heiniger et al., 2015). The favorable impact of coarse silt (its content being inversely proportional to clay content) on the abundance and species richness of Collembola is likely due to the fact that coarse silt (in comparison to clay) reduces soil compaction. Indeed, soil compaction often increases with soil tillage in conventionally cultivated crops where earthworms are scarce (Clements et al., 1991; Imhoff et al., 2016; Nuutinen, 1992). By limiting soil compaction (Håkansson and Lipiec, 2000), known to decrease the abundance of Collembola (Schrader and Lingnau, 1997), a more silty texture could favor a higher abundance and species richness of Collembola. Regarding agricultural practices, our field experiment was conducted in an experimental agricultural research center so that our plots had a long history of conventional use of tillage and pesticides, which can have reduced collembolan biodiversity at start of the experiment (Cortet et al., 2002; Tsiafouli et al., 2015), limiting the response of this microarthropod group to mixtures of varieties, contrary to the field experiment by Chateil et al. (2013), which was under organic farming. This hypothesis is corroborated by the particularly low abundances of Collembola in our field experiment. Although collembolan abundances were within the range found by Cluzeau et al. (2012) and Joimel et al. (2017) in arable lands, they were in average twice to three times lower than in other conventional crop systems in Europe (Cluzeau et al., 2012; Heisler and Kaiser, 1995; Lagerlof and Andren, 1991). The mean local species richness was also relatively low in all plots and was at the lowest level of the range of species richness observed by Cluzeau et al. (2012) for the same sample size.

We observed that the composition of the functional groups of wheat and some traits influence the species richness and abundance of Collembola. Collembolan species richness increased in plots with varieties of the $\mathrm{c} 1$ functional group, which was characterized by a high 
sensitivity to fungal diseases. This effect was supported by the significant impact of two wheat traits: sensitivity to septoria leaf blotch, which was related to increase in both abundance and species richness of Collembola, and specific root length, related to increase in their species richness. However, these effects were weak, and generally twice less as the effect of soil particle size (coarse silt).

Although weak, the effect of wheat composition was higher than that of wheat diversity in our field experiment. Other studies on collembolan populations showed that the effect of plant functional groups was stronger than the effect of plant diversity per se (Milcu et al., 2006; Salamon et al., 2004). However, these studies dealt with functional groups of various plant species and it is the first time that this effect could be demonstrated with groups of plant varieties. Our results suggest that specific root length could contribute to increase collembolan species richness by increasing food resources for soil-dwelling species: the higher the specific root length, the thinner the roots and the shorter their lifespan (Eissenstat et al., 2000). Some collembolan species are known to feed on roots (Thimm and Larink, 1995). Moreover some Collembola, assumed to be mainly decomposers, switch their diet in the presence of plant roots, especially fine roots, and may obtain carbon and nitrogen almost exclusively from plant roots (Eerpina et al., 2017; Endlweber et al., 2009). In the same way, an increase in the sensitivity of wheat varieties to septoria leaf blotch, may increase food resources for fungal-feeding collembolan species (Friberg et al., 2005; Jorgensen et al., 2005; Ponge, 1988). The biomass of fungi and fungal-invaded area of wheat available to Collembola should increase in the more fungal-sensitive wheat varieties.

\subsection{Effect of wheat on species and trait assemblages of Collembola}

Most of the species collected in our study are frequently observed in agricultural crops, e.g. Entomobrya multifasciata, Folsomides parvulus, Heteromurus nitidus, Isotomurus 
palustris, Lepidocyrtus cyaneus, L. lanuginosus, Megalothorax minimus, Neotullbergia ramiscuspis, Parisotoma notabilis, Proisotoma minuta, Pseudosinella alba, Sminthurinus aureus, Sminthurinus elegans (Axelsen and Kristensen, 2000; Frampton et al., 2001; Fratello et al., 1985; Ponge et al., 2003; Querner and Bruckner, 2010; Rebecchi et al., 2000; Sousa et al., 2004).

The number of wheat varieties, the number of functional groups and functional group composition (c1, c2, c3 or c4) did not have any effects on collembolan species and trait assemblages when tested alone. The effect of variety number and functional group composition (especially c2, including varieties with low sensitivity to septoria leaf blotch) together was significant but weak as it explained $9.4 \%$ of the collembolan species distribution. The contribution of functional group composition to explain the distribution of collembolan species and traits was weak but about six times higher (about 6\%) than that of variety number. As for the variety number, the effect of the functional diversity (functional group number) alone was extremely weak (about $1 \%$ ) and not significant. Wheat traits contributed the most to explain the distribution of collembolan species and traits but only about $13 \%$ and $11 \%$, respectively.

Wheat traits related to the sensitivity to fungal diseases and to characteristics of aerial (plant cover) and root parts impacted significantly, although weakly, the distribution of collembolan species and traits. Wheat traits related to aerial parts (plant cover) and root characteristics contributed to explain the distribution of collembolan traits but their effects were not significant when analysed separately. The sensitivity to fungal diseases, and more especially to septoria leaf blotch, were the only trait the effect of which remains significant after deleting the effect of all other variables. Among species associated to wheat varieties sensitive to septoria leaf blotch, Parisotoma notabilis, Sminthurinus elegans and Megalothorax incertus group are known to feed on fungi (Addison et al., 2003; Gillet and 
Ponge, 2005). Other species found in our study, e.g. Pseudosinella alba, Folsomia candida, also known to feed on fungi, including pathogenic species (Mehl, 1996; Meyer-Wolfarth et al., 2017; Ponge and Charpentié, 1981; Ponge, 1988), were not really linked to the sensitivity of wheat varieties to septoria leaf blotch in our graphics. This discrepancy may be explained by the selective attraction of Collembola to fungi (Jorgensen et al., 2005), while the above cited experimental studies concerned fungal pathogens other than Mycosphaerella graminicola (septoria leaf blotch). Isotomurus palustris, another species associated to the sensitivity to septoria leaf blotch, was also less abundant in plots with wheat varieties less sensitive to septoria (c2 functional group), corroborating the influence of this wheat trait. Wheat varieties with both increased sensitivity to fungal diseases and high canopy cover, including high shoot-root ratios, favored logically Collembola living aboveground with morphological traits adapted to aerial life, e.g. with pigmented and spherical body, long furcula and high ocelli number (Salmon et al., 2014). Furthermore, the effect of canopy cover had been observed to impact collembolan populations, the abundance of which decreased indirectly with specific leaf area of oak leaves (Santonja et al., 2018). This is exemplified in our study by Willowsia platani, an epigeic species that was positively influenced by plant cover and is known to search for protection against light and dryness (usually under bark of trees or lichen) (Gisin, 1960).

However, we have to acknowledge that the effect of wheat traits on Collembola communities was very weak. The fact that wheat traits had been measured one year before our field experiment and on different sites, or come from literature, may explain at least partly the weakness of the relationships observed. In fact, a measure of each wheat trait in each plot probably could have better clarified their effect on Collembola communities. The weak effect of wheat traits may also be explained by the low abundances of Collembola in our field experiment, as discussed above. 
Soil features explained about $10 \%$ of the variation in collembolan species and trait

assemblages. Among soil features, coarse silt had the strongest impact on Collembola species and trait distribution. Species living belowground were more abundant in plots with a higher content in coarse silt while species living aboveground (with long appendices, pigmentation and air-sensitive bristles) were more abundant in plots with lower content in coarse silt (and thus more clayish and compact). This finding corroborates the role of coarse silt suggested above (section 4.1), i.e. attenuating soil compaction and allowing more euedaphic Collembola to live belowground, while in soils with less coarse silt (and thus more clayish and compact) epigeic species (here Sminthurides signatus, Entomobrya cf. multifasciata, Sminthurinus aureus and aureus group, Lepidocyrtus cyaneus) were probably more abundant than euedaphic species because of the reduction in the number and size of soil pores (Schrader and Lingnau, 1997).

The increase in wheat diversity did not foster collembolan species diversity, corroborating some previous studies failing to show an effect of plant diversity on soil fauna communities. This may be due to the fact that (1) wheat varieties most suitable to Collembola were underrepresented, (2) the overall low collembolan diversity in the experimental plots prevented an increase in local species richness with wheat diversity, and (3) soil features, especially particle size distribution (texture), impacted collembolan distribution despite our efforts (seedling randomization) to take this natural effect in account in our experimental design. Moreover, our results show that the composition of plant populations, including functional composition, has a greater impact (although low) than intraspecific plant diversity on collembolan communities. They showed significant although weak effects of the composition of wheat functional groups that likely provide more resources and/or a larger niche volume (more roots and more fungal pathogens) suitable to Collembola. This suggests that mixtures with wheat varieties having a higher specific root length could be chosen to 
increase collembolan species richness by providing more habitat and food. Moreover, our

559 study suggests that keeping in mixture some wheat varieties with a lower resistance to fungal diseases (e.g. by selecting other traits related to higher yield) could be compensated by the consumption of fungal pathogens by Collembola (Sabatini et al., 2000), which would contribute to increase collembolan species richness. This greater effect of the composition of wheat varieties could explain why our results, contrast with those of a previous study (Chateil et al., 2013), which showed that wheat genetic diversity increased the species richness of several groups of invertebrates, including Collembola. In fact, the field experiment of Chateil et al. (2013) encompassed a low number of wheat varieties, and the varieties added in the higher level of diversity were probably all beneficial to Collembola.

\section{Conclusions}

Our study showed no effect of genetic wheat diversity on Collembola communities and weak although significant effects of wheat variety composition and traits. In fact, soil features, especially particle size, impacted more strongly Collembola than wheat composition or diversity. Our study suggests that, at least in conventional agroecosystems, other factors such as soil features, but also perhaps the surrounding landscape or agricultural practices contribute more to structuring collembolan communities than intraspecific diversity. Studying the effect of the diversity of wheat varieties using the same experimental method (high number of varieties and four levels of diversity, respectively) but in crops grown in organic farming, and with more homogenous soil features (if possible), could allow better assessing the impact of intraspecific diversity and composition of plants on soil invertebrate communities. A measure of each functional wheat trait during the experiment would also allow to directly assess potential impacts of wheat traits on Collembola. 
This work was supported by the ANR WHEATAMIX project, grant ANR-13-AGRO5840008 of the French National Research Agency. The authors thank all the persons who were 585 involved in the management of the field experiment, and particularly Dr. Jérôme Enjalbert, 586 Dr. Sébastien Saint-Jean, and Christophe Montagnier. The authors gratefully thank Pr. 587 Emmanuelle Porcher for constructive comments and recommendations which helped to 588 improve quality of the paper. 
Abrams, P., 1983. The theory of limiting similarity. Annu. Rev. Ecol. Syst . 14, 359-376.

Axelsen, J.A., Kristensen, K.T., 2000. Collembola and mites in plots fertilised with different types of green manure. Pedobiologia 44, 556-566.

Barot, S., Allard, V., Cantarel, A., Enjalbert, J., Gauffreteau, A., Goldringer, I., Lata, J.C., Le Roux, X., Niboyet, A., Porcher, E., 2017a. Designing mixtures of varieties for multifunctional agriculture with the help of ecology. A review. Agronomy for Sustainable Development 37.

Barot, S., Ye, L., Abbadie, L., Blouin, M., Frascaria-Lacoste, N., 2017b. Ecosystem services must tackle anthropized ecosystems andecological engineering. Ecological Engineering 99, 486-495.

Bengtsson, J., Ahnstrom, J., Weibull, A.C., 2005. The effects of organic agriculture on biodiversity and abundance: a meta-analysis. Journal of Applied Ecology 42, 261-269.

Bonnin, I., Bonneuil, C., Goffaux, R., Montalent, P., Goldringer, I., 2014. Explaining the decrease in the genetic diversity of wheat in France over the 20th century. Agriculture Ecosystems \& Environment 195, 183-192.

Borg, J., Kiaer, L.P., Lecarpentier, C., Goldringer, I., Gauffreteau, A., Saint-Jean, S., Barot, S., Enjalbert, J., 2018. Unfolding the potential of wheat cultivar mixtures: A metaanalysis perspective and identification of knowledge gaps. Field Crops Research 221, 298-313.

Bretfeld, G., 1999. Synopses on Palaearctic Collembola. Volume 2. Symphypleona. Abhandlungen und Berichte des Naturkundemuseums Goerlitz 71, 1-318.

Castagneyrol, B., Jactel, H., 2012. Unraveling plant-animal diversity relationships: a metaregression analysis. Ecology 93, 2115-2124.

Chateil, C., Goldringer, I., Tarallo, L., Kerbiriou, C., Le Viol, I., Ponge, J.F., Salmon, S., Gachet, S., Porcher, E., 2013. Crop genetic diversity benefits farmland biodiversity in cultivated fields. Agriculture Ecosystems \& Environment 171, 25-32.

Clements, R.O., Murray, P.J., Sturdy, R.G., 1991. The impact of 20 years' absence of earthworms and three levels of $\mathrm{N}$ fertilizer on a grassland soil environment. Agriculture, Ecosystems \& Environment 36, 75-85.

Cluzeau, D., Guernion, M., Chaussod, R., Martin-Laurent, F., Villenave, C., Cortet, J., RuizCamacho, N., Pernin, C., Mateille, T., Philippot, L., Bellido, A., Rougé, L., Arrouays, D., Bispo, A., Pérès, G., 2012. Integration of biodiversity in soil quality monitoring: Baselines for microbial and soil fauna parameters for different land-use types. European Journal of Soil Biology 49, 63-72.

Cortet, J., Ronce, D., Poinsot-Balaguer, N., Beaufreton, C., Chabert, A., Viaux, P., de Fonseca, J.P.C., 2002. Impacts of different agricultural practices on the biodiversity of microarthropod communities in arable crop systems. European Journal of Soil Biology $38,239-244$.

Crawford, K.M., Crutsinger, G.M., Sanders, N.J., 2007. Host-plant genotypic diversity mediates the distribution of an ecosystem engineer. Ecology 88, 2114-2120.

Crutsinger, G.M., Collins, M.D., Fordyce, J.A., Gompert, Z., Nice, C.C., Sanders, N.J., 2006. Plant genotypic diversity predicts community structure and governs an ecosystem process. Science 313, 966-968.

de Vries, F.T., Thébault, E., Liiri, M., Birkhofer, K., Tsiafouli, M.A., Bjørnlund, L., Bracht Jørgensen, H., Brady, M.V., Christensen, S., de Ruiter, P.C., d'Hertefeldt, T., Frouz, J., Hedlund, K., Hemerik, L., Hol, W.H.G., Hotes, S., Mortimer, S.R., Setälä, H., Sgardelis, S.P., Uteseny, K., van der Putten, W.H., Wolters, V., Bardgett, R.D., 2013. Soil food web properties explain ecosystem services across European land use 
systems. Proceedings of the National Academy of Sciences of the United States of America 110, 14296-14301.

Dubs, X. Le Roux, V. Allard, B. Andrieu, S. Barot, A. Cantarel, C. de Vallavielle-Pope, A., Gauffreteau, I.G., C. Montagnier, T. Pommier, E. Porcher, S. Saint-Jean, J. Borg, S., Bourdet-Massein, D.C., A. Duclouet, E. Forst, N. Galic, L. Gerard, M. Hugoni, A. Hure, A., Larue, J.-C.L., C. Lecarpentier, M. Leconte, E. Le Saux, I. Le Viol, P. L'hote, P. Lusley, M., Mouchet, A.N., j, R. Perronne, E. Pichot, S. Pin, S. Salmon, D. Tropée, A. Vergnes,1, T. Vidal,, Enjalbert, J., 2018a. An experimental design to test the effect of wheat variety mixtures on biodiversity and ecosystem services. HAL Id: hal-01843564.

Dubs, F., Vergnes, A., Mirlicourtois, E., Le Viol, I., Kerbiriou, C., Goulnik, J., Belghali, S., Bentze, L., Barot, S., Porcher, E., 2018b. Positive effects of wheat variety mixtures on aboveground arthropods are weak and variable. Basic and Applied Ecology.

Duffy, J.E., Cardinale, B.J., France, K.E., McIntyre, P.B., Thebault, E., Loreau, M., 2007. The functional role of biodiversity in ecosystems: incorporating trophic complexity. Ecology Letters 10, 522-538.

Ebeling, A., S. Pompe, J. Baade, N. Eisenhauer, H. Hillebrand, R. Proulx, C. Roscher, B. Schmid, C. Wirth, and W. W. Weisser. 2014. A trait-based experimental approach to understand the mechanisms underlying biodiversity-ecosystem functioning relationships. Basic and Applied Ecology 15, 229-240.

Eerpina, R., Boiteau, G., Lynch, D.H., 2017. Collembola diet switching in the presence of maize roots varies with species. Canadian Journal of Soil Science 97, 171-177.

Eisenhauer, N., Milcu, A., Sabais, A.C.W., Bessler, H., Brenner, J., Engels, C., Klarner, B., Maraun, M., Partsch, S., Roscher, C., Schonert, F., Temperton, V.M., Thomisch, K., Weigelt, A., Weisser, W.W., Scheu, S., 2011. Plant Diversity Surpasses Plant Functional Groups and Plant Productivity as Driver of Soil Biota in the Long Term. PLOS ONE 6.

Endlweber, K., Ruess, L., Scheu, S., 2009. Collembola switch diet in presence of plant roots thereby functioning as herbivores. Soil Biology \& Biochemistry 41, 1151-1154.

Endlweber, K., Scheu, S., 2007. Interactions between mycorrhizal fungi and Collembola: effects on root structure of competing plant species. Biology and Fertility of Soils 43, 741-749.

Finney, D.M., Kaye, J.P., 2017. Functional diversity in cover crop polycultures increases multifunctionality of an agricultural system. Journal of Applied Ecology 54, 509-517.

Frampton, G.K., Van den Brink, P.J., Wratten, S.D., 2001. Diel activity patterns in an arable collembolan community. Applied Soil Ecology 17, 63-80.

Fratello, B., Bertolani, R., Sabatini, M.A., Mola, L., Rassu, M.A., 1985. Effects of atrazine on soil microarthropods in experimental maize fields. Pedobiologia 28, 161-168.

Friberg, H., Lagerlöf, J., Rämert, B., 2005. Influence of soil fauna on fungal plant pathogens in agricultural and horticultural systems. Biocontrol Science and Technology 15, 641658.

Grossi, J.L., Brun, J.J., 1997. Effect of climate and plant succession on lumbricid populations in the French Alps. Soil Biology and Biochemistry 29, 329-333.

Håkansson, I., Lipiec, J., 2000. A review of the usefulness of relative bulk density values in studies of soil structure and compaction. Soil and Tillage Research 53, 71-85.

Heiniger, C., Barot, S., Ponge, J.F., Salmon, S., Meriguet, J., Carmignac, D., Suillerot, M., Dubs, F., 2015. Collembolan preferences for soil and microclimate in forest and pasture communities. Soil Biology \& Biochemistry 86, 181-192. 
Heisler, C., Kaiser, E.-A., 1995. Influence of agricultural traffic and crop management on collembola and microbial biomass in arable soil. Biology and Fertility of Soils 19, 159-165.

Hopkin, S.P., 1997. Biology of the Springtails (Insecta: Collembola). Oxford University Press Oxford.

Hopkin, S.P., 2007. A Key to the Springtails (Collembola) of Britain and Ireland. . Field Studies Council (AIDGAP Project). 245pp. pp.

Imhoff, S., Pires da Silva, A., Ghiberto, P., Tormena, C., Pilatti , M., Libardi, P., 2016. Physical Quality Indicators and Mechanical Behavior of Agricultural Soils of Argentina. PLoS ONE 11, e0153827. .

Isbell, F., Craven, D., Connolly, J., Loreau, M., Schmid, B., Beierkuhnlein, C., Bezemer, T.M., Bonin, C., Bruelheide, H., de Luca, E., Ebeling, A., Griffin, J.N., Guo, Q., Hautier, Y., Hector, A., Jentsch, A., Kreyling, J., Lanta, V., Manning, P., Meyer, S.T., Mori, A.S., Naeem, S., Niklaus, P.A., Polley, H.W., Reich, P.B., Roscher, C., Seabloom, E.W., Smith, M.D., Thakur, M.P., Tilman, D., Tracy, B.F., van der Putten, W.H., van Ruijven, J., Weigelt, A., Weisser, W.W., Wilsey, B., Eisenhauer, N., 2015. Biodiversity increases the resistance of ecosystem productivity to climate extremes. Nature advance online publication.

Jeanneret, P., Schupbach, B., Luka, H., 2003. Quantifying the impact of landscape and habitat features on biodiversity in cultivated landscapes. Agriculture Ecosystems \& Environment 98, 311-320.

Johnson, M.T.J., Lajeunesse, M.J., Agrawal, A.A., 2006. Additive and interactive effects of plant genotypic diversity on arthropod communities and plant fitness. Ecology Letters 9, 24-34.

Joimel, S., Schwartz, C., Hedde, M., Kiyota, S., Krogh, P.H., Nahmani, J., Pérès, G., Vergnes, A., Cortet, J., 2017. Urban and industrial land uses have a higher soil biological quality than expected from physicochemical quality. Science of the Total Environment 584-585, 614-621.

Jones, T.S., Allan, E., Harri, S.A., Krauss, J., Muller, C.B., van Veen, F.J.F., 2011. Effects of genetic diversity of grass on insect species diversity at higher trophic levels are not due to cascading diversity effects. Oikos 120, 1031-1036.

Jorgensen, H.B., Johansson, T., Canback, B., Hedlund, K., Tunlid, A., 2005. Selective foraging of fungi by collembolans in soil. Biology Letters 1, 243-246.

Lagerlof, J., Andren, O., 1991. ABUNDANCE AND ACTIVITY OF COLLEMBOLA, PROTURA AND DIPLURA (INSECTA, APTERYGOTA) IN 4 CROPPING SYSTEMS. Pedobiologia 35, 337-350.

Legendre, P., Legendre, L., 1998. Numerical Ecology. Second english edition. Elsevier, Amsterdam, $853 \mathrm{pp}$.

Litrico, I., Goldringer, I., Enjalbert, J., 2015. Plus-value de la diversité génétique intraparcelle pour la stabilité de la production et autres services écosystémiques. Innovations Agronomiques 43, 7-18.

Loeuille, N., Barot, S., Georgelin, E., Kylafis, G., Lavigne, C., 2013. Eco-Evolutionary Dynamics of Agricultural Networks: Implications for Sustainable Management, In: Woodward, G., Bohan, D.A. (Eds.), Advances in Ecological Research, Vol 49: Ecological Networks in an Agricultural World. Elsevier Academic Press Inc, San Diego, pp. 339-435.

Loreau, M., Hector, A., 2001. Partitioning selection and complementarity in biodiversity experiments. Nature 412, 72-76. 
McArt, S.H., Cook-Patton, S.C., Thaler, J.S., 2012. Relationships between arthropod richness, evenness, and diversity are altered by complementarity among plant genotypes. Oecologia 168, 1013-1021.

Mehl, F., 1996. Frassaktivitat von Collembolen (Isotomina thermophila, Heteromurus nitidus, Folsomia candida) an drei verschiedenen, bodenburtigen, phytopathogenen Schadpilzen der Gattung Fusarium (F. subglutinans, F. graminearum, F. oxysporum). Pflanzenschutzberichte 56, 1-23.

Meyer-Wolfarth, F., Schrader, S., Oldenburg, E., Weinert, J., Brunotte, J., 2017. Collembolans and soil nematodes as biological regulators of the plant pathogen Fusarium culmorum. Journal of Plant Diseases and Protection 124, 493-498.

Milcu, A., Partsch, S., Langel, R., Scheu, S., 2006. The response of decomposers (earthworms, springtails and microorganisms) to variations in species and functional group diversity of plants. Oikos 112, 513-524.

Ngosong, C., Gabriel, E., Ruess, L., 2014. Collembola grazing on arbuscular mycorrhiza fungi modulates nutrient allocation in plants. Pedobiologia 57, 171-179.

Nuutinen, V., 1992. Earthworm community response to tillage and residue management on different soil types in southern finland. Soil \& Tillage Research 23, 221-239.

Ponge, J.-F., Charpentié, M.-J., 1981. Etude des relations microflore-microfaune : expériences sur Pseudosinella alba (Packard), Collembole mycophage. Revue d'Ecologie et Biologie du Sol 18, 291-303.

Ponge, J.-F., Gillet, S., Dubs, F., Fedoroff, E., Haese, H., Sousa, J.P., Lavelle, P., 2003. Collembolan communities as bioindicators of land use intensification. Soil Biology and Biochemistry 35, 813-826.

Ponge, J.F., 1988. Ecological study of a forest humus by observing a small volume III. The F1 layer from a moder humus under pinus-sylvestris. Pedobiologia 31, 1-64.

Potapow, M., 2001. Synopses on Palaearctic Collembola. Volume 3. Isotomidae, 1-603 pp.

Prieto, I., Violle, C., Barre, P., Durand, J.-L., Ghesquiere, M., Litrico, I., 2015. Complementary effects of species and genetic diversity on productivity and stability of sown grasslands. Nature Plants 1.

Querner, P., Bruckner, A., 2010. Combining pitfall traps and soil samples to collect Collembola for site scale biodiversity assessments. Applied Soil Ecology 45, 293-297.

Rebecchi, L., Sabatini, M.A., Cappi, C., Grazioso, P., Vicari, A., Dinelli, G., Bertolani, R., 2000. Effects of a sulfonylurea herbicide on soil microarthropods. Biology and Fertility of Soils 30, 312-317.

Ricotta, C., Moretti, M., 2011. CWM and Rao's quadratic diversity: a unified framework for functional ecology. Oecologia 167, 181-188.

Salamon, J.A., Schaefer, M., Alphei, J., Schmid, B., Scheu, S., 2004. Effects of plant diversity on Collembola in an experimental grassland ecosystem. Oikos 106, 51-60.

Salmon, S., Ponge, J.F., Gachet, S., Deharveng, L., Lefebvre, N., Delabrosse, F., 2014. Linking species, traits and habitat characteristics of Collembola at European scale. Soil Biology \& Biochemistry 75, 73-85.

Santonja, M., Aupic-Samain, A., Forey, E., Chauvat, M., 2018. Increasing temperature and decreasing specific leaf area amplify centipede predation impact on Collembola. European Journal of Soil Biology 89, 9-13.

Schrader, S., Lingnau, M., 1997. Influence of soil tillage and soil compaction on microarthropods in agricultural land. Pedobiologia 41, 202-209.

Schrader, S., Wolfarth, F., Oldenburg, E., 2013. Biological Control of Soil-borne Phytopathogenic Fungi and their Mycotoxins by Soil Fauna A review. Bulletin of University of Agricultural Sciences and Veterinary Medicine Cluj-Napoca Agriculture 70, 291-298. 
Sousa, J.P., da Gama, M.M., Pinto, P., Keating, A., Calhoa, F., Lemos, M., Castro, C., Luz, T., Leitao, P., Dias, S., 2004. Effects of land-use on Collembola diversity patterns in a Mediterranean landscape. Pedobiologia 48, 609-622.

Tenenhaus, M., 1998. La Régression PLS, Théorie et Pratique. . Editions Technips, Paris, 254 pp.

Ter Braak, C., J. F. , 1986. Canonical Correspondence Analysis: A New Eigenvector Technique for Multivariate Direct Gradient Analysis. Ecology 67, 1167-1179.

Thibaud, J.-M., Schulz, H.-J., da Gama Assalino, M.M., 2004. Synopses on Palaearctic Collembola Hypogastruridae. Abhandlungen und Berichte des Naturkundemuseums Goerlitz 75, 1-287.

Thimm, T., Larink, O., 1995. Grazing preferences of some Collembola for endomycorrhizal fungi. Biology and Fertility of Soils 19, 266-268.

Tooker, J.F., Frank, S.D., 2012. Genotypically diverse cultivar mixtures for insect pest management and increased crop yields. Journal of Applied Ecology 49, 974-985.

Tsiafouli, M.A., Thebault, E., Sgardelis, S.P., de Ruiter, P.C., van der Putten, W.H., Birkhofer, K., Hemerik, L., de Vries, F.T., Bardgett, R.D., Brady, M.V., Bjornlund, L., Jorgensen, H.B., Christensen, S., D' Hertefeldt, T., Hotes, S., Hol, W.H.G., Frouz, J., Liiri, M., Mortimer, S.R., Setala, H., Tzanopoulos, J., Uteseny, K., Pizl, V., Stary, J., Wolters, V., Hedlund, K., 2015. Intensive agriculture reduces soil biodiversity across Europe. Global Change Biology 21, 973-985.

Viketoft, M., Sohlenius, B., 2011. Soil nematode populations in a grassland plant diversity experiment run for seven years. Applied Soil Ecology 48, 174-184.

Weisser, W. W., C. Roscher, S. T. Meyer, A. Ebeling, G. Luo, E. Allan, H. Beßler, R. L. Barnard, N. Buchmann, F. Buscot, C. Engels, C. Fischer, M. Fischer, A. Gessler, G. Gleixner, S. Halle, A. Hildebrandt, H. Hillebrand, H. de Kroon, M. Lange, S. Leimer, X. Le Roux, A. Milcu, L. Mommer, P. A. Niklaus, Y. Oelmann, R. Proulx, J. Roy, C. Scherber, M. Scherer-Lorenzen, S. Scheu, T. Tscharntke, M. Wachendorf, C. Wagg, A. Weigelt, W. Wilcke, C. Wirth, E.-D. Schulze, B. Schmid, and N. Eisenhauer. 2017. Biodiversity effects on ecosystem functioning in a 15-year grassland experiment: Patterns, mechanisms, and open questions. Basic and Applied Ecology 23, 1-73.

Warnock, A. J., Flitter, A. H., Usher, M. B., 1982. The influence of a springtail Folsomia candida (Insecta, Collembola) on the mycorrhizal association of leek Allium porrum and the vesicular-arbuscular mycorrhizal endophyte Glomus fasciculatus. New Phytologist 90, 285-292.

Zhu, Y.Y., Chen, H.R., Fan, J.H., Wang, Y.Y., Li, Y., Chen, J.B., Fan, J.X., Yang, S.S., Hu, L.P., Leung, H., Mew, T.W., Teng, P.S., Wang, Z.H., Mundt, C.C., 2000. Genetic diversity and disease control in rice. Nature 406, 718-722. 
825 Table 1. Wheat trait in mixtures of varieties and their codes used in our statistical analyses.

\begin{tabular}{ll}
\hline Trait code & Wheat trait in mixtures of varieties \\
\hline SRL & Mean specific root length $\left({\left.\mathrm{m} . \mathrm{g}^{-1}\right)}\right.$ \\
\hline SRR & Mean shoot/root ratio \\
\hline RD & Mean root diameter $(\mathrm{mm})$ \\
\hline GAIT1 & Mean Green Area Index in December = ratio of leaf green area to ground \\
& Mean sensitivity to yellow rust (mean percentage of sporulating area) \\
\hline YR & Mean sensitivity to septoria leaf blotch (mean percentage of sporulating \\
\hline Septo & area) \\
\hline GAIT6 & Mean of Green Area Index in April = ratio of leaf green area to ground \\
& area
\end{tabular}

826 
Table 2. Analysis of Deviance Table (Type II Wald chisquare tests) (Chisquare, P-value) from final

829 models with abundance and species richness of Collembola as response variables respectively, soil

830 features+ variety number+ functional group composition or soil features+ functional group number+

831 wheat traits, as explanatory variables. Only explanatory variables showing a significant effect were

832 kept in the final model (See Tables S4 to S7 for details). See Table 1 for wheat trait codes; Co-silt: the

833 amount of coarse silt; C1, C2: C1 and C2 functional groups of wheat.

\begin{tabular}{|c|c|c|c|c|c|}
\hline & Final model & $\begin{array}{c}\text { Explanatory } \\
\text { variables }\end{array}$ & $\begin{array}{l}\text { Degrees of } \\
\text { freedom }\end{array}$ & Chisquare & P-value \\
\hline \multirow[b]{2}{*}{$\begin{array}{l}\text { Species } \\
\text { richness }\end{array}$} & $\mathrm{C} 1+\mathrm{Co}-\mathrm{silt}$ & $\begin{array}{c}\text { Co-silt } \\
\text { C1 }\end{array}$ & $\begin{array}{l}1 \\
1\end{array}$ & $\begin{array}{l}16.4311 \\
7.9275\end{array}$ & $\begin{array}{r}5.045 \mathrm{e}-05 \\
0.004869\end{array}$ \\
\hline & $\begin{array}{c}\text { SRL+Septo+Co- } \\
\text { silt }\end{array}$ & $\begin{array}{c}\text { SRL } \\
\text { Septo } \\
\text { Co-silt }\end{array}$ & $\begin{array}{l}1 \\
1 \\
1\end{array}$ & $\begin{array}{l}4.0832 \\
7.9036 \\
20.1757\end{array}$ & $\begin{array}{c}0.043311 \\
0.004934 \\
7.065 \mathrm{e}-06\end{array}$ \\
\hline \multirow[b]{2}{*}{ Abundance } & $\mathrm{C} 2+\mathrm{Co}-$ silt & $\begin{array}{l}\text { Co-silt } \\
\text { C2 }\end{array}$ & $\begin{array}{l}1 \\
1\end{array}$ & $\begin{array}{l}17.1698 \\
3.2121\end{array}$ & $\begin{array}{r}3.418 \mathrm{e}-05 \\
0.07309\end{array}$ \\
\hline & Septo+Co-silt & $\begin{array}{l}\text { Septo } \\
\text { Co-silt }\end{array}$ & $\begin{array}{l}1 \\
1\end{array}$ & $\begin{array}{l}9.7172 \\
20.1981\end{array}$ & $\begin{array}{l}0.001826 \\
6.982 \mathrm{e}-06\end{array}$ \\
\hline
\end{tabular}

834 
837 Table 3. Names and codes of Collembola species

\begin{tabular}{|c|c|}
\hline Species name & Code \\
\hline Desoria tigrina & Destig \\
\hline Deuterosminthurus sp. & Deutersp \\
\hline Entomobrya lanuginosa & Entlan \\
\hline Entomobrya sp. cf multifasciata & Entmul \\
\hline Entomobryoides purpurascens & Entpur \\
\hline Entomobrya sp. & Entsp \\
\hline Folsomia candida & Folcan \\
\hline Folsomides parvulus & Folpar \\
\hline Heteromurus nitidus & Hetnit \\
\hline Isotomurus antennalis & Isoant \\
\hline Isotomurus palustris & Isopal \\
\hline Lepidocyrtus cyaneus & Lepcya \\
\hline Lepidocyrtus lanuginosus & Leplan \\
\hline Lepidocyrtus lignorum & Leplig \\
\hline Megalothorax group incertus & Meginc \\
\hline Megalothorax group minimus & Megmin \\
\hline Mesaphorura sp. & Messp \\
\hline Neotullbergia ramicuspis & Neoram \\
\hline Parisotoma notabilis & Parnot \\
\hline Proisotoma minima & Promini \\
\hline Proisotoma minuta & Prominu \\
\hline Pseudosinella alba & Psealb \\
\hline Seira domestica & Seidom \\
\hline Sminthurinus aureus & Smiaur \\
\hline Sminthurides signatus & Smisig \\
\hline Sminthurinus group aureus & Smigraur \\
\hline
\end{tabular}




\begin{tabular}{ll}
\hline Sminthurinus elegans & Smiele \\
\hline Willowsia platani & Wilpla \\
\hline
\end{tabular}

838

839

840 
842 Table 4. Names and codes of Collembola traits. Micro-habitats (Epi, Eda, Hemi-Eda) were attributed 843 from micro-habitats where species are usually collected (they are not life forms deduced from 844 morphological traits, see Salmon et al. 2014)

\begin{tabular}{ll}
\hline \multicolumn{1}{c}{ Trait code } & \multicolumn{1}{c}{ Trait name } \\
\hline ReproPart & Parthenogenetic reproduction \\
ReproSex & Sexual reproduction \\
\hline SpheB & Spherical body \\
CylB & Cylindrical body \\
\hline BodyL & Body length \\
\hline FurcaL & Furcula length \\
\hline LegL & Leg length \\
\hline AntL & Antenna length (wearing sensory organ) \\
\hline Ocel & Number of ocelli (visual organ) \\
\hline PAOVes & Max number of PAO vesicles (sensory organ) \\
\hline Tricho & Trichobothria (sensory organ) \\
\hline Scal & Scales (protective feature) \\
\hline Pigm & Pigmentation (UV protection) \\
\hline Psoc & Pseudocelli (defense against predators) \\
\hline Epi & Micro-habitat Epigeic (above soil surface) \\
\hline Eda & Micro-habitat Edaphic (soil) \\
\hline Hemieda & Micro-habitat Hemiedaphic (litter) \\
\hline Hemi-Eda & Micro-habitat Hemiedaphic \& Edaphic (litter and soil) \\
\hline NS & No specialisation for micro-habitat (depth) \\
\hline
\end{tabular}




\section{Figure captions}

849 Fig. 1. Box-plots of log-transformed abundance (a, decimal logarithm of the number of individuals in 3 pooled samples) and species richness (b, number of species in 3 pooled samples) of Collembola for each number of wheat varieties (varnb): 1, 2, 4 and 8 varieties per plot. Upper, lower and median bands of boxes, crosses and dots represent first and third quartiles, median, average, minimum and maximum values, respectively. The ends of whiskers are calculated using 1.5 times the interquartile space (distance between 1st and 3rd quartiles).

Fig. 2. Abundance (a, decimal logarithm of the number of individuals in 3 pooled samples) and species richness (b, number of species in 3 pooled samples) of Collembola as a function of the standardized mean sensitivity to septoria ( $a, b$, percentage of leaf area covered by septoria), and specific root length (c) of wheat in each plot. Each dot represents one plot.

Fig. 3. Canonical correspondence analysis (CCA) showing the distribution and assemblage of species (active variables) constrained by the number of wheat variety (nbvar) and the presence of the $c 2$ functional group (5a), three wheat traits (5b) and three soil features (5c) along the first two canonical axes F1 and F2. Explicative variables (c2 functional group, nbvar, Septo, GAIT1, Septo, Co-silt, pH, C_N) were the variables that impacted the most the collembolan assemblies as shown by the CCA PLS. Co-silt: Coarse silt ; $\mathrm{C} / \mathrm{N}$ : soil carbon to nitrogen ratio, $\mathrm{pH}$ : soil $\mathrm{pH}$. See Table 1 for wheat trait abbreviations and Table 3 for Collembola species name abbreviations 
871 Fig. 4. Redundancy analysis (RDA) showing the distribution and assembly of community

872

873

874

875

876

877

878

879

880

881

882

883

884

\section{9} weighted-mean (CWM) collembolan functional traits (active variables) constrained by two wheat traits (a) and four soil features (b) along canonical axes F1 and F2. Septo: sensitivity to Septoria; YR: sensitivity to Yellow rust ; Co-silt: Coarse silt; C/N: soil carbon to nitrogen ratio; $\mathrm{pH}$ : soil $\mathrm{pH}$; Water: soil water content. See Table1 for wheat trait abbreviations. See Table 4 for collembolan trait abbreviations, Table S1 for collembolan trait values and Salmon et al. (2014) for more details about collembolan traits. 


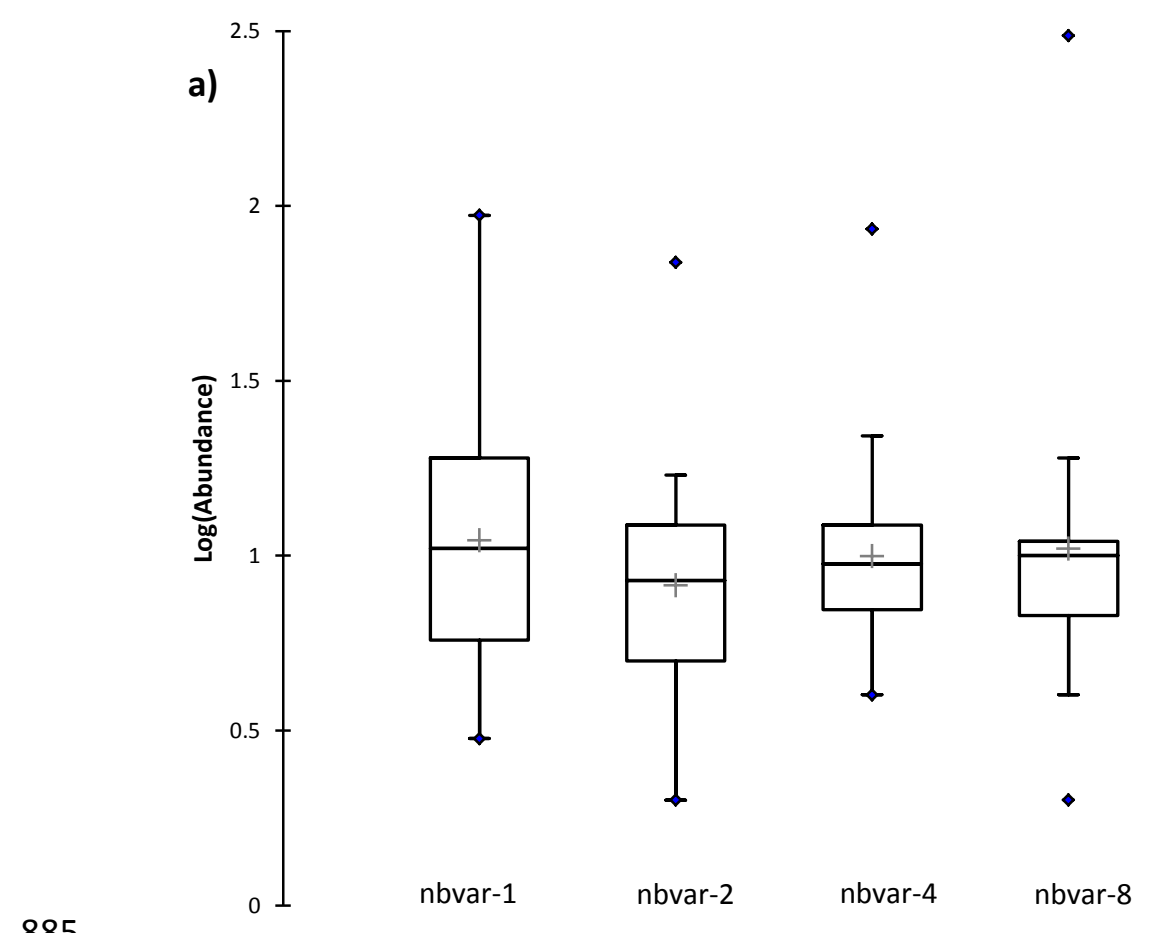

885

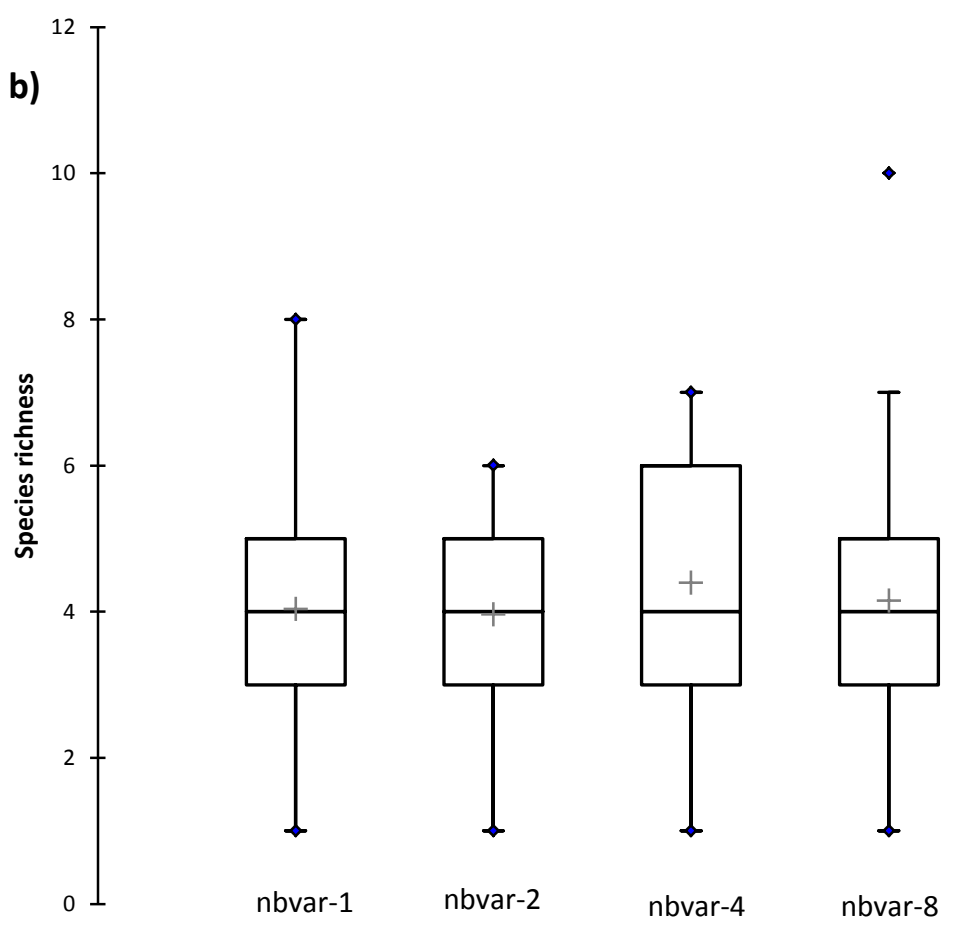

Figure 1

890

891

892 


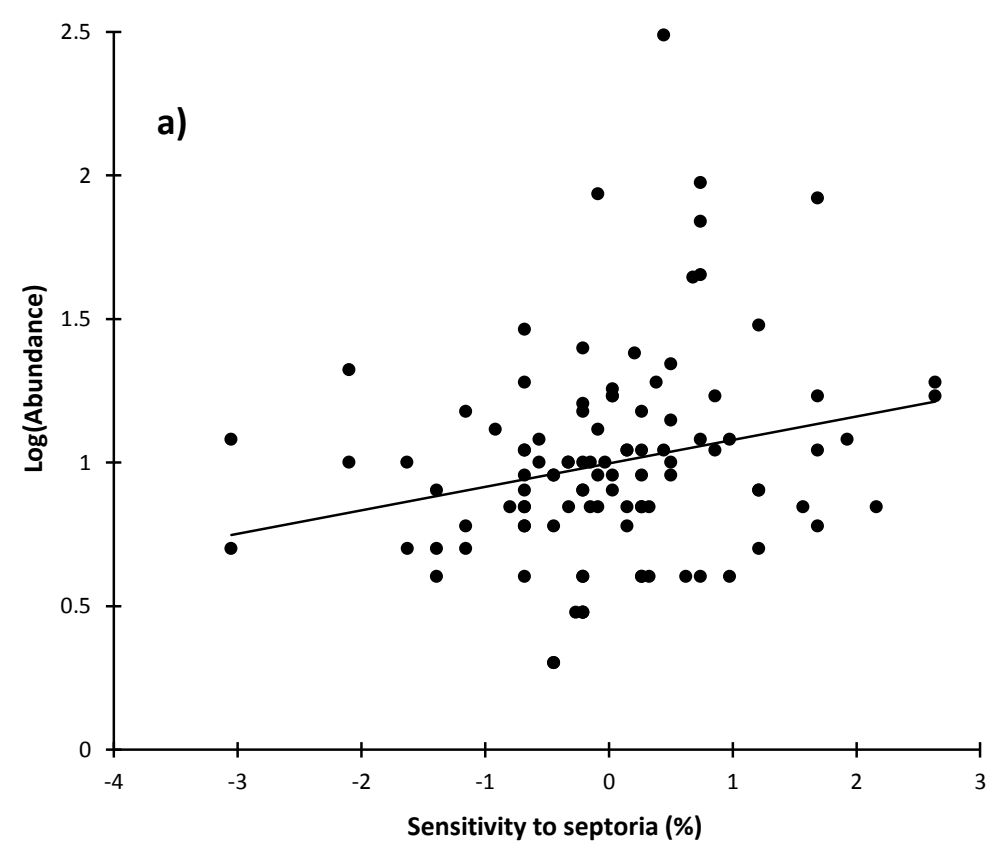

910

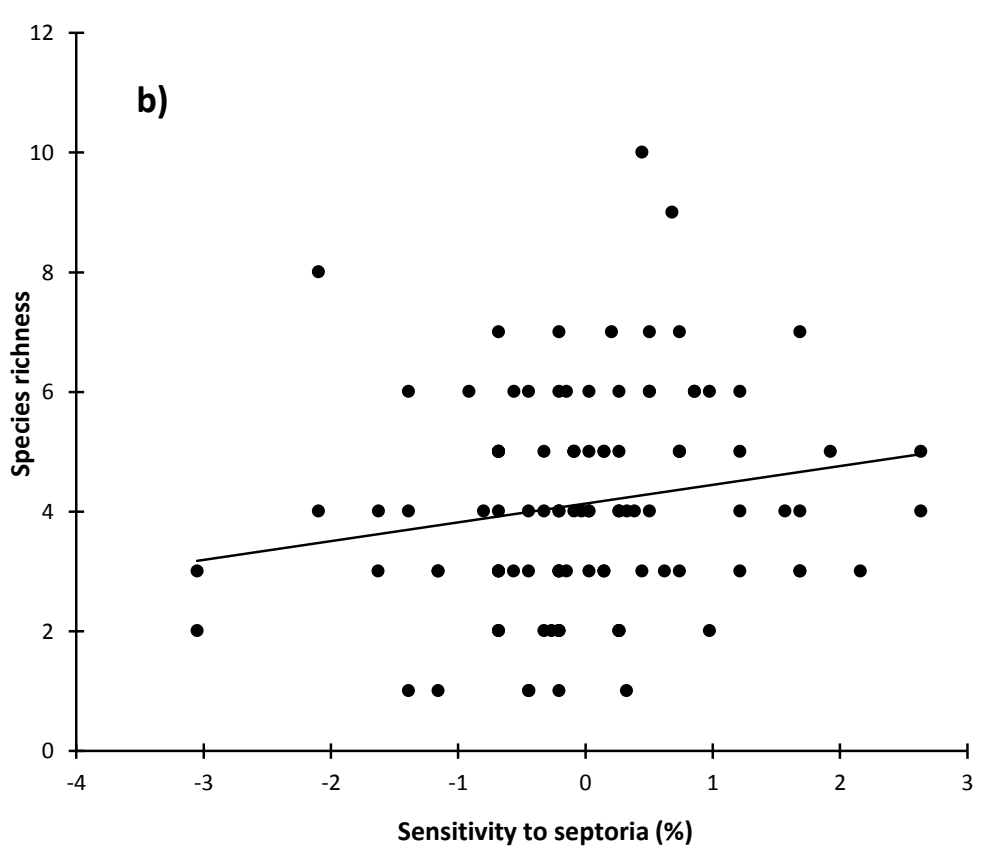




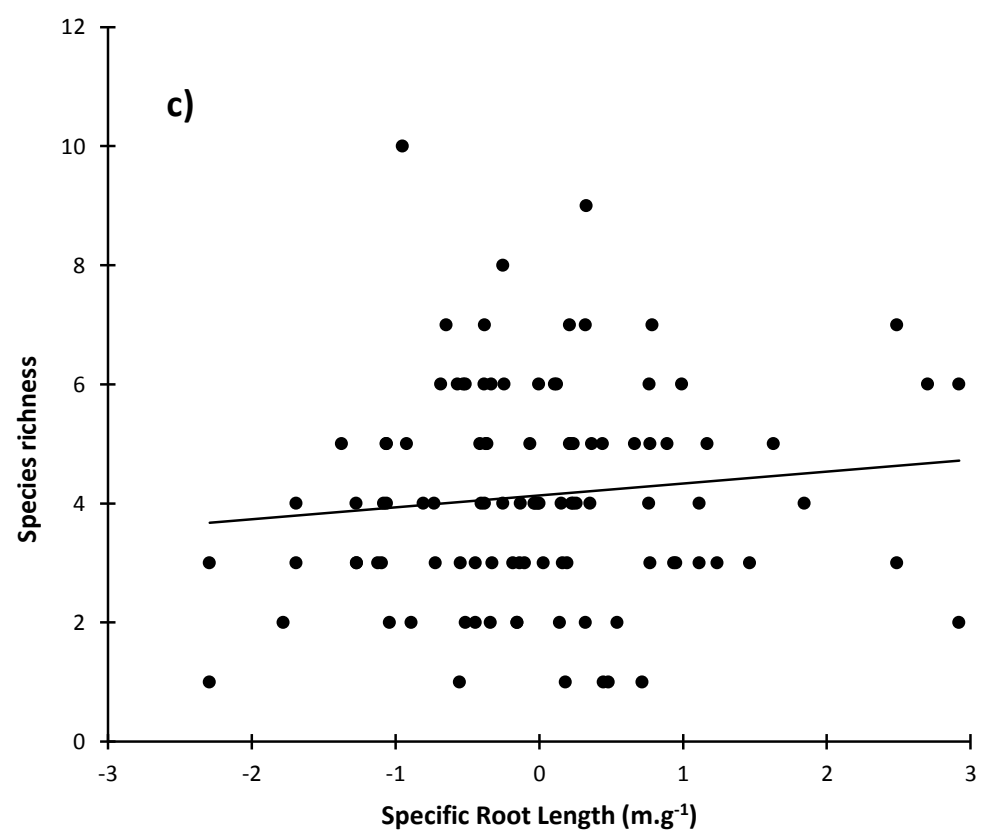

914 Figure 2

915

916

917

918

919 


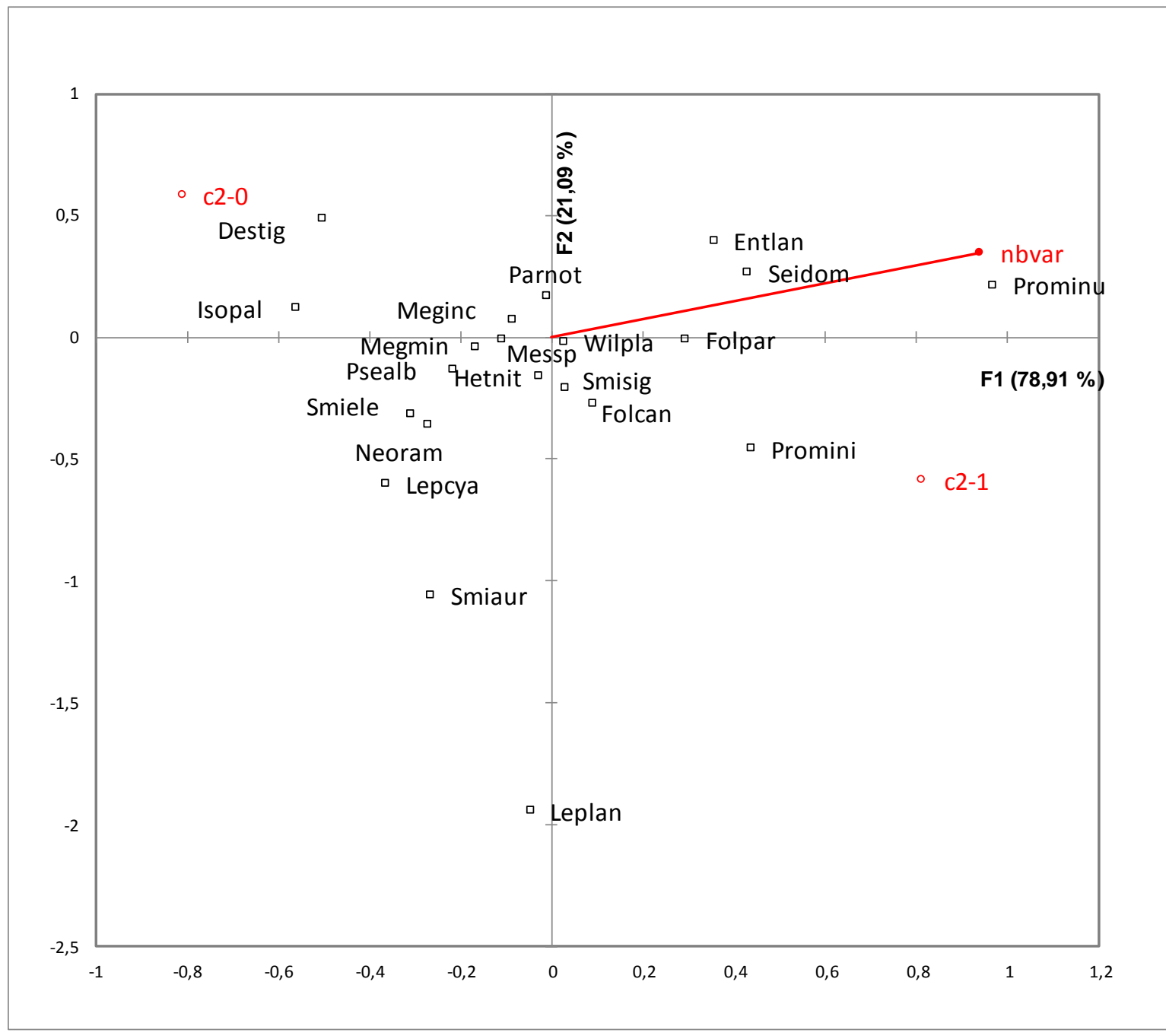

922

923 Figure 3a

924

925

926

927

928

929

930

931

932

933 


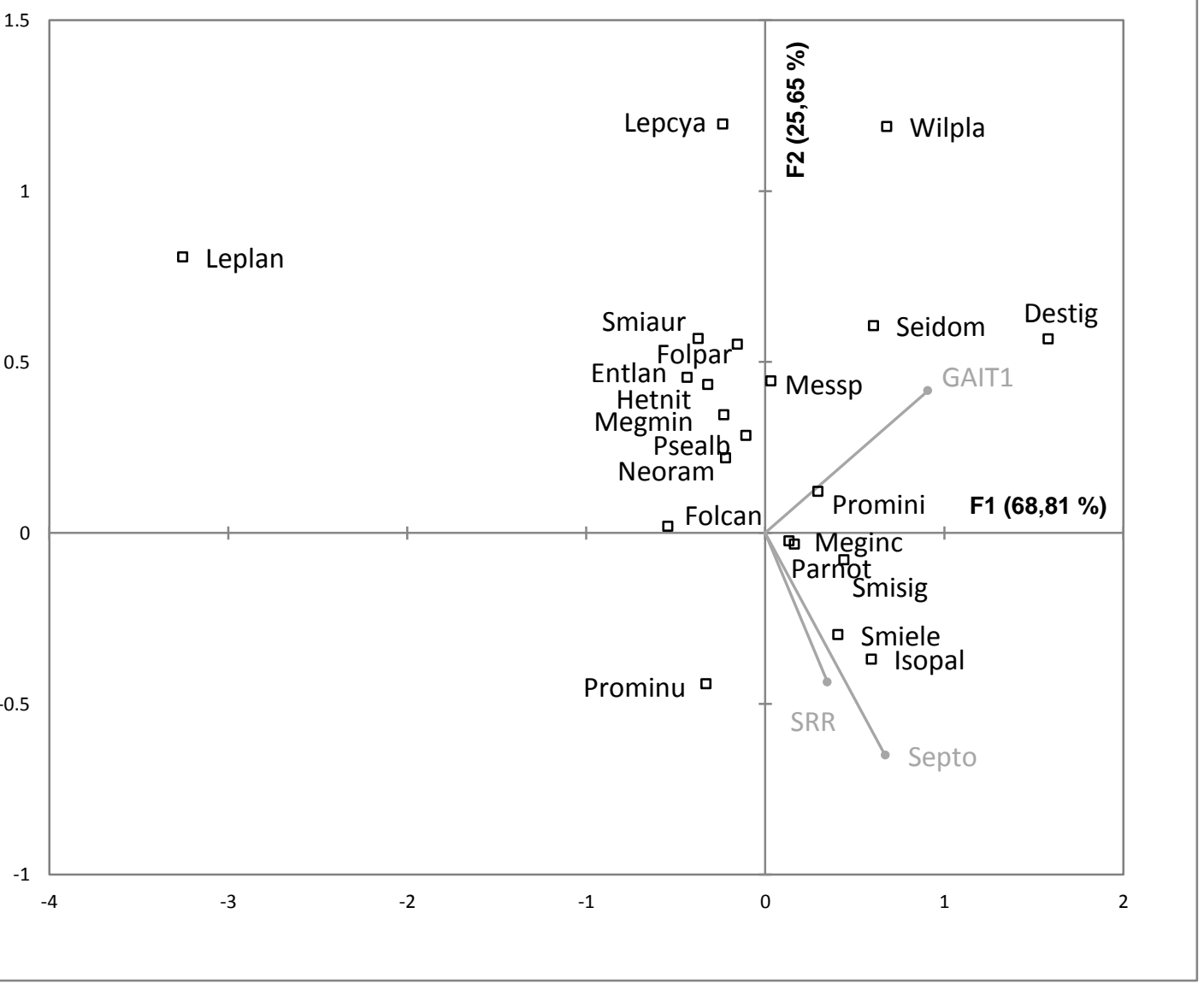

935

936 Figure $3 b$ 


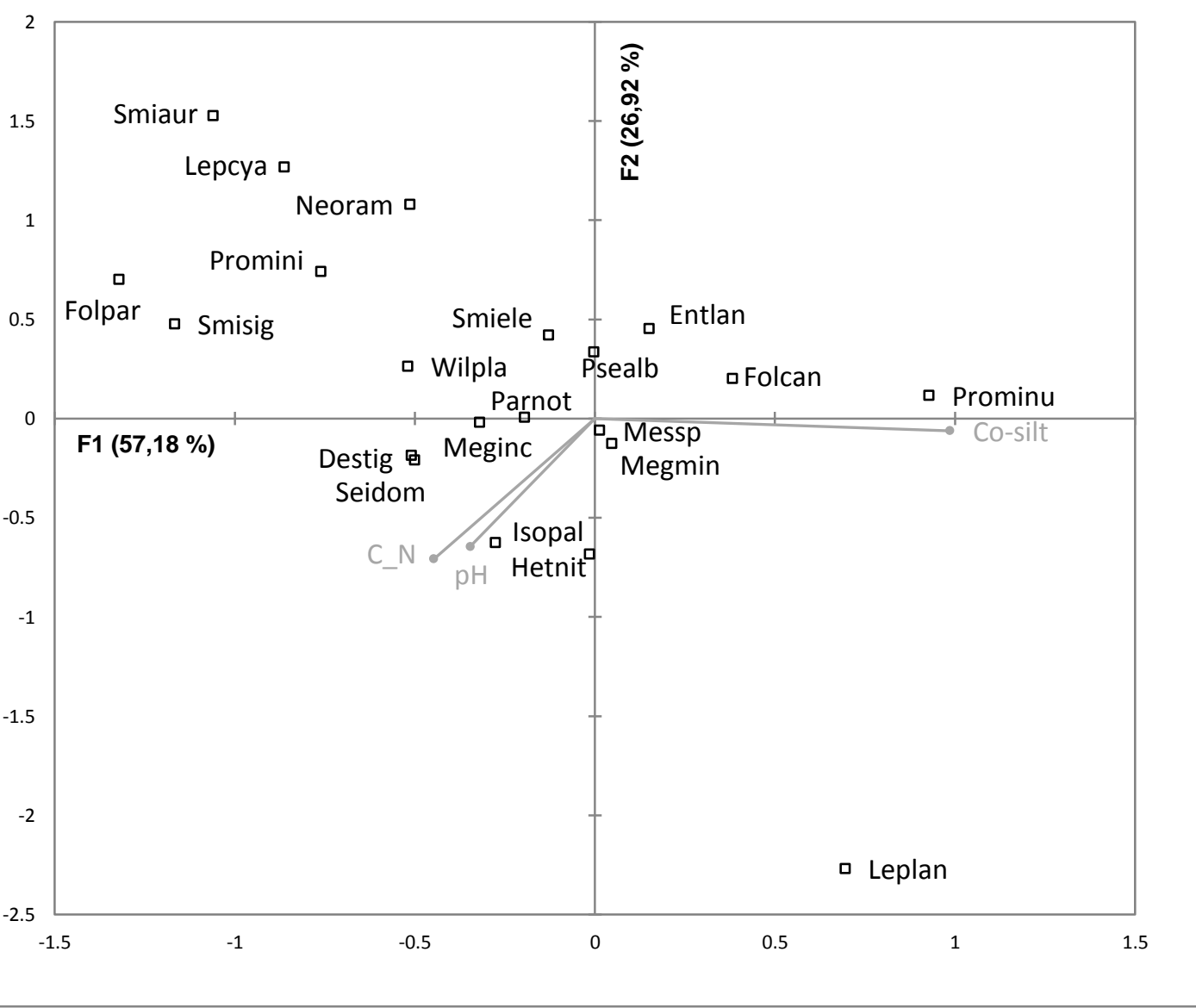




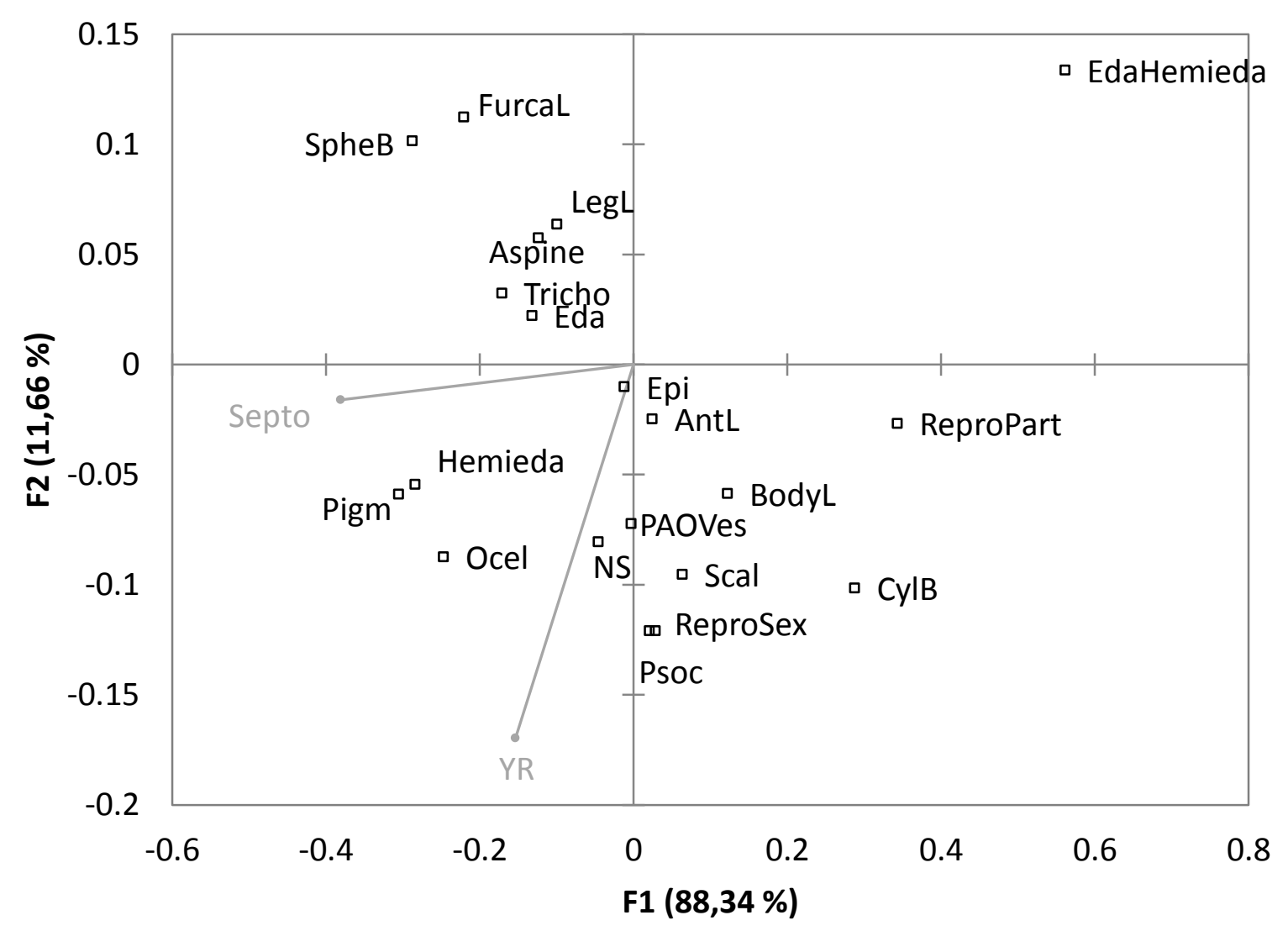




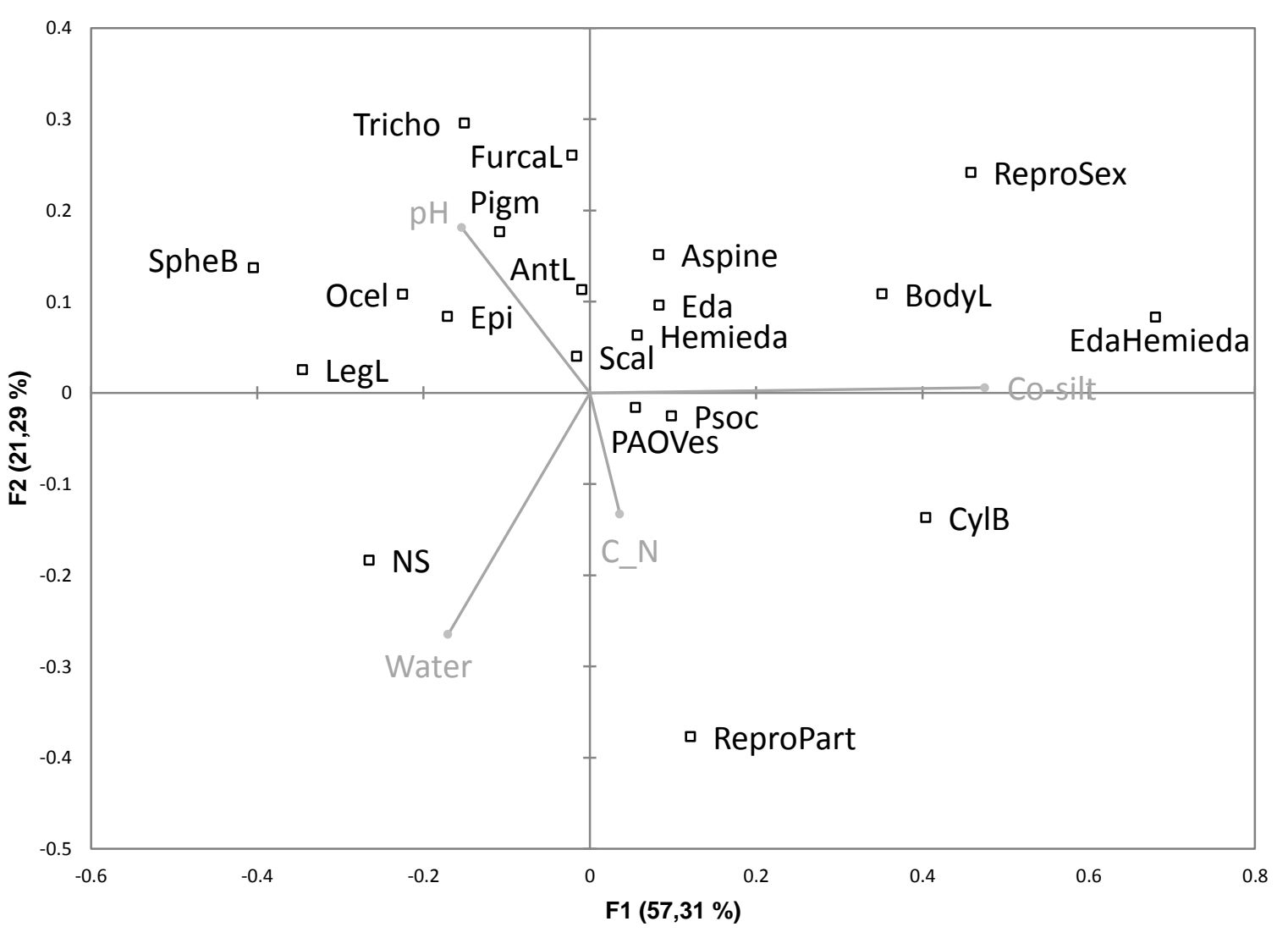


948

949

950

951

952

953 Figure S1 : Part of the experimental design of randomized plots in the Wheatamix project.

954 Orange : pure (1 variety) ; Pink :2 varieties ; Green :4 varieties, Yellow : 8 varieties ;

955 Red : commercial varieties, not taken into account in the present study. Grey bands : Triticale 


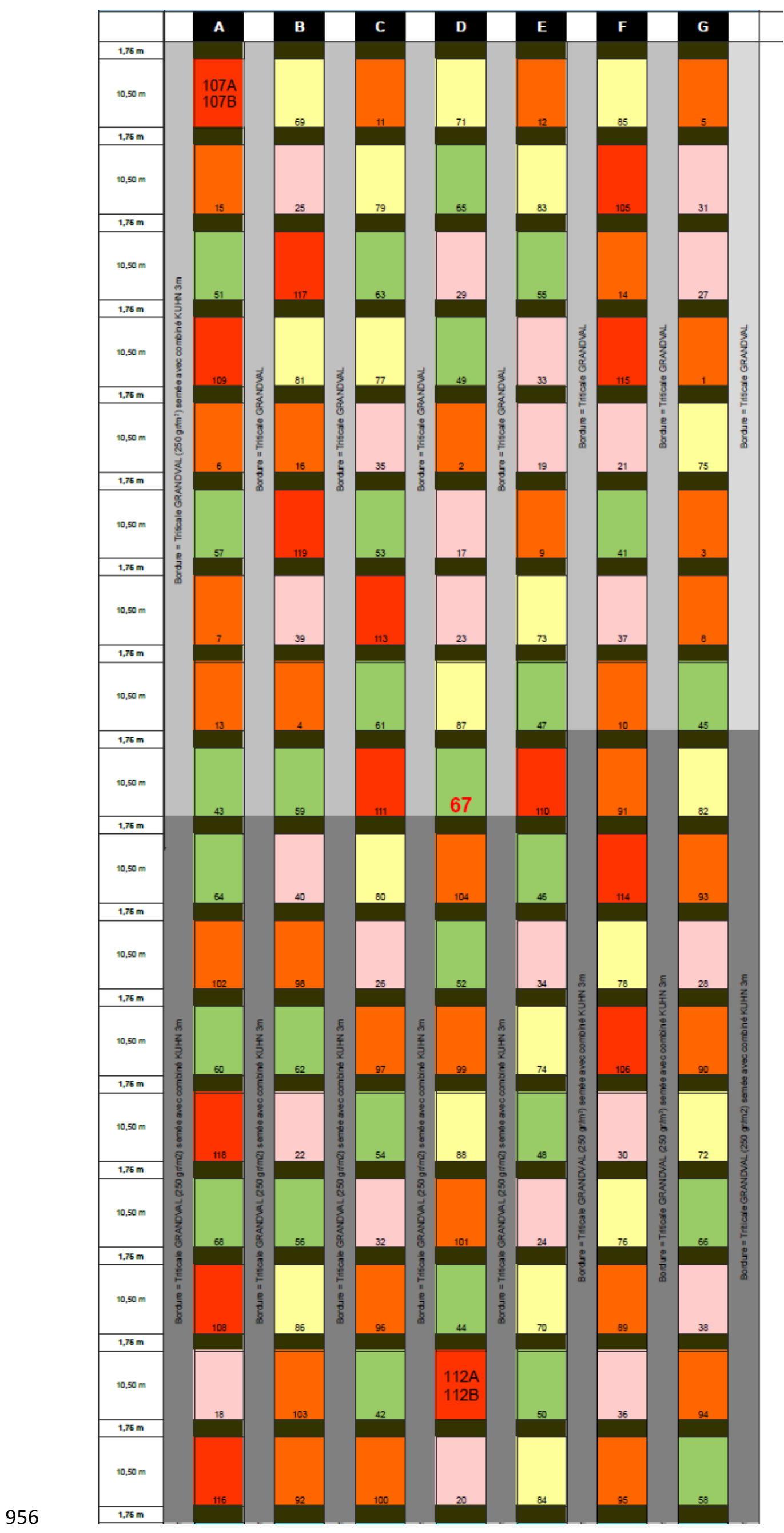


Box plots (RS)

957

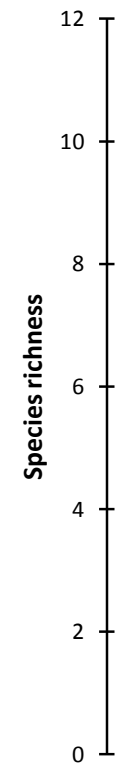

958

959

960 Fig. S2. Box-plots of species richness (number of species in 3 pooled samples) of Collembola,

961 comparing plots without (c1-absent) and with (c1-present) the $\mathrm{c} 1$ functional group. See Figure 1 for the meaning of boxes, whiskers, crosses and dots.

963

964

965 


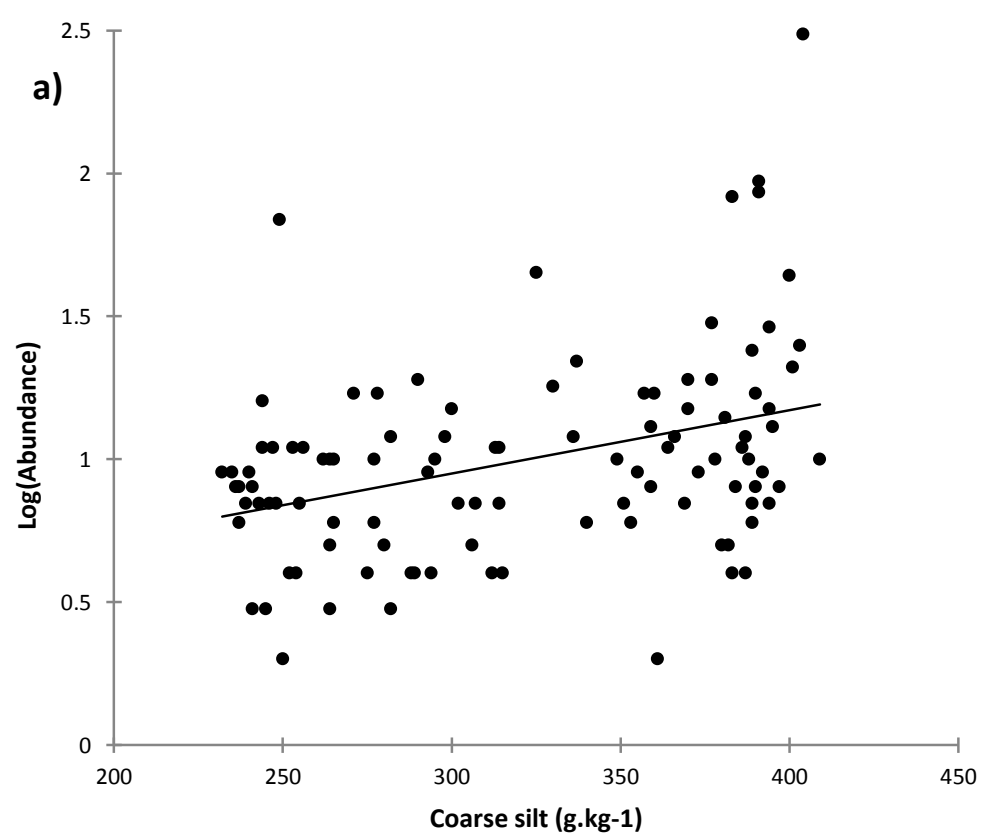

966

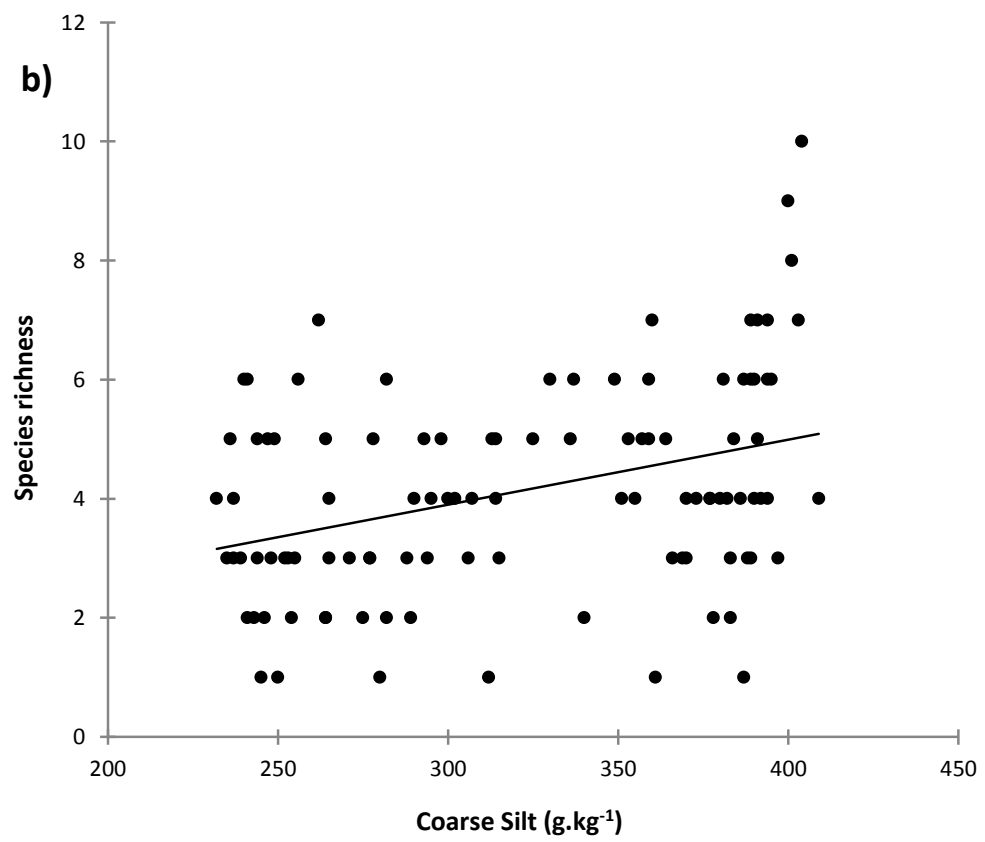

Figure S3. Log-transformed abundance (a, decimal logarithm of the number of individuals in

9713 pooled samples) and species richness (b, number of species in 3 pooled samples) of 972 Collembola as a function of the amount of coarse silt $(20-50 \mu \mathrm{m})$ in soil. Each dot represents 973 one plot. 

1 Table S1: Values of Collembola traits (see Table S1 and S2 for abbreviations of species and trait names)

\begin{tabular}{|c|c|c|c|c|c|c|c|c|c|c|c|c|c|c|c|c|}
\hline & $\begin{array}{l}\text { Repro } \\
\text { Sex }\end{array}$ & $\begin{array}{l}\text { Repro } \\
\text { Part }\end{array}$ & CylB & SpheB & Scal & Pigm & BodyL & Ocel & FurcaL & AntL & $\begin{array}{l}\text { PAO } \\
\text { Ves }\end{array}$ & Tricho & Psoc & LegL & Aspine & $\begin{array}{l}\text { Micro- } \\
\text { Habitat }\end{array}$ \\
\hline Destig & 1 & 0 & 1 & 0 & 0 & 1 & 2.1 & 8 & 4 & 1.35 & 1 & 0 & 0 & 0.3 & 0 & NS \\
\hline Deusp & 1 & 0 & 1 & 0 & 0 & 1 & 0.75 & 8 & 4 & 1.87 & 0 & 1 & 0 & 0.486 & 0 & NS \\
\hline Entlan & 1 & 0 & 1 & 0 & 0 & 0 & 2 & 8 & 4 & 2.337 & 0 & 1 & 0 & 0.47 & 0 & Epi \\
\hline Entmul & 1 & 0 & 1 & 0 & 0 & 1 & 1.75 & 8 & 4 & 2.407 & 0 & 1 & 0 & 0.46 & 0 & Epi \\
\hline Entpur & 1 & 0 & 1 & 0 & 0 & 1 & 1.5 & 8 & 4 & 2.35 & 0 & 1 & 0 & 0.6 & 0 & Epi \\
\hline Entsp & 1 & 0 & 1 & 0 & 0 & 0 & 1.975 & 8 & 4 & 2.7175 & 0 & 1 & 0 & 0.452 & 0 & Epi \\
\hline Folcan & 1 & 1 & 1 & 0 & 0 & 0 & 1.85 & 0 & 3 & 1.25 & 1 & 0 & 0 & 0.28 & 0 & Hemi- Eda \\
\hline Folpar & 0 & 1 & 1 & 0 & 0 & 0 & 0.9 & 2 & 2 & 0.9 & 1 & 0 & 0 & 0.5 & 0 & NS \\
\hline Hetnit & 1 & 0 & 1 & 0 & 1 & 1 & 2.25 & 2 & 4 & 2 & 0 & 1 & 0 & 0.49 & 0 & Hemi- Eda \\
\hline Isoant & 1 & 0 & 1 & 0 & 0 & 1 & 2.2 & 8 & 4 & 2 & 1 & 0 & 0 & 0.413 & 0 & Hemieda \\
\hline Isopal & 1 & 0 & 1 & 0 & 0 & 1 & 2.7 & 8 & 4 & 2 & 1 & 1 & 0 & 0.4 & 0 & NS \\
\hline Lepcya & 1 & 0 & 1 & 0 & 1 & 1 & 1.5 & 8 & 4 & 1.4 & 0 & 1 & 0 & 0.3925 & 0 & Epi \\
\hline Leplan & 1 & 0 & 1 & 0 & 1 & 1 & 2 & 8 & 4 & 1.6 & 0 & 1 & 0 & 0.455 & 0 & NS \\
\hline Leplig & 1 & 0 & 1 & 0 & 1 & 1 & 1.8 & 8 & 4 & 1.5 & 0 & 1 & 0 & 0.48 & 0 & NS \\
\hline Meginc & 0 & 0 & 0 & 1 & 0 & 0 & 0.5 & 0 & 4 & 0.5 & 0 & 1 & 0 & 0.51 & 1 & Eda \\
\hline Megmin & 0 & 0 & 1 & 0 & 0 & 0 & 0.4 & 0 & 4 & 0.5 & 0 & 1 & 0 & 0.5 & 1 & Eda \\
\hline
\end{tabular}




\begin{tabular}{|c|c|c|c|c|c|c|c|c|c|c|c|c|c|c|c|c|}
\hline Messsp & 1 & 1 & 1 & 0 & 0 & 0 & 0.582 & 0 & 0 & 0 & 31.8 & 0 & 14 & 0.11 & 1 & Eda \\
\hline Neoram & 1 & 0 & 1 & 0 & 0 & 0 & 1 & 0 & 0 & 0.72 & 60 & 0 & 14 & 0.14 & 1 & Eda \\
\hline Parnot & 1 & 1 & 1 & 0 & 0 & 1 & 1.2 & 5 & 4 & 0.95 & 1 & 0 & 0 & 0.34 & 0 & Hemieda \\
\hline Promini & 1 & 1 & 1 & 0 & 0 & 0 & 0.8 & 5 & 2 & 1.05 & 1 & 0 & 0 & 0.12 & 0 & NS \\
\hline Prominu & 1 & 0 & 1 & 0 & 0 & 1 & 1.2 & 8 & 2 & 0.85 & 1 & 0 & 0 & 0 & 0 & Epi \\
\hline Psealb & 1 & 0 & 1 & 0 & 1 & 0 & 1.05 & 2 & 4 & 1.8 & 0 & 1 & 0 & 0.51 & 0 & Eda \\
\hline Seidom & 1 & 0 & 1 & 0 & 1 & 0 & 3 & 8 & 4 & 2.8 & 0 & 1 & 0 & 0 & 0 & NS \\
\hline Smiaur & 1 & 0 & 0 & 1 & 0 & 1 & 1 & 8 & 4 & 1 & 0 & 1 & 0 & 0.6 & 0 & Epi \\
\hline Smidsig & 1 & 0 & 0 & 1 & 0 & 1 & 0.3 & 8 & 4 & 1.57 & 0 & 1 & 0 & 0.49 & 0 & Epi \\
\hline Smigraur & 1 & 0 & 0 & 1 & 0 & 1 & 0.85 & 8 & 4 & 1.2 & 0 & 1 & 0 & 0.6 & 0 & Epi \\
\hline Sminele & 1 & 0 & 0 & 1 & 0 & 1 & 0.7 & 8 & 4 & 1.4 & 0 & 1 & 0 & 0.6 & 0 & Epi \\
\hline Wilpla & 1 & 0 & 1 & 0 & 1 & 1 & 3 & 8 & 4 & 2.64 & 0 & 1 & 0 & 0.34 & 1 & Epi \\
\hline
\end{tabular}


4 Table S2: see Excel file

Table S2. Abundances of Collembola species in three pooled samples of 104

plots of the Wheatamix project

nbvar: number of wheat varieties; nbclu: number of clusters (wheat functional groups)

See table 3 for the name of Collembola species

Table S3: Spearman correlation coefficients between explanatory variables 


\begin{tabular}{|c|c|c|c|c|c|c|c|c|c|c|c|c|c|c|c|c|c|c|c|c|c|c|}
\hline Variables & nbvar & nbclu & SRR & RDMC & RGR & SRL & $\mathrm{RD}$ & GAIT1 & GAIT6 & Yellow-Rust & Septo & $x D D$ & $y D D$ & Clay & Fi-Silt & Co-Silt & Fi-Sand & Co-Sand & $\mathrm{N}$ & $\mathrm{C} / \mathrm{N}$ & Corg & OM \\
\hline nbvar & 1 & 0,800 & 0,180 & 0,120 & $-0,055$ & 0,062 & 0,027 & 0,018 & 0,081 & 0,070 & 0,026 & $-0,002$ & 0,031 & $-0,039$ & $-0,094$ & $-0,051$ & 0,117 & 0,028 & $-0,088$ & 0,031 & $-0,072$ & $-0,076$ \\
\hline nbclu & 0,800 & 1 & 0,126 & 0,108 & $-0,052$ & 0,064 & 0,023 & 0,019 & 0,069 & 0,066 & 0,049 & $-0,045$ & 0,060 & $-0,075$ & $-0,068$ & $-0,010$ & 0,056 & 0,023 & $-0,124$ & 0,079 & $-0,073$ & $-0,075$ \\
\hline SRR & 0,180 & 0,126 & 1 & 0,056 & $-0,275$ & 0,300 & 0,333 & 0,255 & 0,051 & 0,004 & 0,178 & $-0,201$ & $-0,377$ & 0,315 & $-0,166$ & $-0,285$ & 0,221 & 0,265 & 0,314 & $-0,166$ & 0,156 & 0,155 \\
\hline RDMC & 0,120 & 0,108 & 0,056 & 1 & 0,695 & $-0,581$ & 0,052 & $-0,235$ & 0,147 & 0,111 & 0,099 & 0,035 & 0,066 & $-0,024$ & 0,081 & 0,070 & $-0,142$ & $-0,027$ & $-0,018$ & 0,042 & $-0,018$ & $-0,021$ \\
\hline RGR & $-0,055$ & $-0,052$ & $-0,275$ & 0,695 & 1 & $-0,928$ & 0,009 & $-0,206$ & 0,067 & 0,277 & 0,303 & 0,203 & 0,078 & $-0,030$ & 0,014 & 0,053 & $-0,129$ & $-0,002$ & $-0,033$ & 0,190 & 0,063 & 0,065 \\
\hline$S R L$ & 0,062 & 0,064 & 0,300 & $-0,581$ & $-0,928$ & 1 & 0,065 & 0,280 & $-0,204$ & $-0,228$ & $-0,208$ & $-0,242$ & $-0,045$ & 0,011 & 0,021 & $-0,020$ & 0,090 & $-0,016$ & $-0,012$ & $-0,188$ & $-0,109$ & $-0,110$ \\
\hline RD & 0,027 & 0,023 & 0,333 & 0,052 & 0,009 & 0,065 & 1 & $-0,059$ & $-0,030$ & 0,095 & 0,450 & $-0,053$ & $-0,089$ & 0,026 & 0,017 & $-0,024$ & 0,033 & $-0,009$ & 0,058 & $-0,031$ & 0,052 & 0,054 \\
\hline GAIT1 & 0,018 & 0,019 & 0,255 & $-0,235$ & $-0,206$ & 0,280 & $-0,059$ & 1 & $-0,191$ & 0,473 & 0,262 & 0,064 & $-0,131$ & 0,135 & $-0,277$ & $-0,226$ & 0,291 & 0,203 & 0,108 & 0,005 & 0,111 & 0,113 \\
\hline GAIT6 & 0,081 & 0,069 & 0,051 & 0,147 & 0,067 & $-0,204$ & $-0,030$ & $-0,191$ & 1 & $-0,450$ & $-0,036$ & $-0,047$ & $-0,048$ & 0,111 & $-0,033$ & $-0,064$ & 0,014 & 0,069 & 0,053 & $-0,039$ & 0,020 & 0,018 \\
\hline Yellow-Rust & 0,070 & 0,066 & 0,004 & 0,111 & 0,277 & $-0,228$ & 0,095 & 0,473 & $-0,450$ & 1 & 0,486 & 0,240 & 0,040 & $-0,056$ & $-0,117$ & 0,000 & 0,058 & 0,015 & 0,012 & 0,197 & 0,155 & 0,159 \\
\hline Septo & 0,026 & 0,049 & 0,178 & 0,099 & 0,303 & $-0,208$ & 0,450 & 0,262 & $-0,036$ & 0,486 & 1 & 0,040 & $-0,110$ & 0,101 & $-0,154$ & $-0,116$ & 0,099 & 0,135 & 0,039 & 0,063 & 0,100 & 0,103 \\
\hline xDD & $-0,002$ & $-0,045$ & $-0,201$ & 0,035 & 0,203 & $-0,242$ & $-0,053$ & 0,064 & $-0,047$ & 0,240 & 0,040 & 1 & $-0,097$ & 0,212 & $-0,278$ & $-0,252$ & 0,224 & 0,247 & 0,314 & 0,710 & 0,646 & 0,646 \\
\hline yDD & 0,031 & 0,060 & $-0,377$ & 0,066 & 0,078 & $-0,045$ & $-0,089$ & $-0,131$ & $-0,048$ & 0,040 & $-0,110$ & $-0,097$ & 1 & $-0,845$ & 0,648 & 0,867 & $-0,723$ & $-0,793$ & $-0,823$ & 0,134 & $-0,628$ & $-0,627$ \\
\hline Clay & $-0,039$ & $-0,075$ & 0,315 & $-0,024$ & $-0,030$ & 0,011 & 0,026 & 0,135 & 0,111 & $-0,056$ & 0,101 & 0,212 & $-0,845$ & 1 & $-0,681$ & $-0,861$ & 0,643 & 0,799 & 0,814 & $-0,027$ & 0,679 & 0,679 \\
\hline Fi-Silt & $-0,094$ & $-0,068$ & $-0,166$ & 0,081 & 0,014 & 0,021 & 0,017 & $-0,277$ & $-0,033$ & $-0,117$ & $-0,154$ & $-0,278$ & 0,648 & $-0,681$ & 1 & 0,833 & $-0,895$ & $-0,808$ & $-0,586$ & $-0,112$ & $-0,572$ & $-0,570$ \\
\hline Co-Silt & $-0,051$ & $-0,010$ & $-0,285$ & 0,070 & 0,053 & $-0,020$ & $-0,024$ & $-0,226$ & $-0,064$ & 0,000 & $-0,116$ & $-0,252$ & 0,867 & $-0,861$ & 0,833 & 1 & $-0,878$ & $-0,935$ & $-0,785$ & 0,024 & $-0,659$ & $-0,658$ \\
\hline Fi-Sand & 0,117 & 0,056 & 0,221 & $-0,142$ & $-0,129$ & 0,090 & 0,033 & 0,291 & 0,014 & 0,058 & 0,099 & 0,224 & $-0,723$ & 0,643 & $-0,895$ & $-0,878$ & 1 & 0,767 & 0,634 & $-0,025$ & 0,535 & 0,534 \\
\hline Co-Sand & 0,028 & 0,023 & 0,265 & $-0,027$ & $-0,002$ & $-0,016$ & $-0,009$ & 0,203 & 0,069 & 0,015 & 0,135 & 0,247 & $-0,793$ & 0,799 & $-0,808$ & $-0,935$ & 0,767 & 1 & 0,714 & 0,040 & 0,630 & 0,628 \\
\hline $\mathrm{C} / \mathrm{N}$ & 0,031 & 0,079 & $-0,166$ & 0,042 & 0,190 & $-0,188$ & $-0,031$ & 0,005 & $-0,039$ & 0,197 & 0,063 & 0,710 & 0,134 & $-0,027$ & $-0,112$ & 0,024 & $-0,025$ & 0,040 & $-0,032$ & 1 & 0,490 & 0,490 \\
\hline Corg & $-0,072$ & $-0,073$ & 0,156 & $-0,018$ & 0,063 & $-0,109$ & 0,052 & 0,111 & 0,020 & 0,155 & 0,100 & 0,646 & $-0,628$ & 0,679 & $-0,572$ & $-0,659$ & 0,535 & 0,630 & 0,836 & 0,490 & 1 & 1,000 \\
\hline OM & $-0,076$ & $-0,075$ & 0,155 & $-0,021$ & 0,065 & $-0,110$ & 0,054 & 0,113 & 0,018 & 0,159 & 0,103 & 0,646 & $-0,627$ & 0,679 & $-0,570$ & $-0,658$ & 0,534 & 0,628 & 0,835 & 0,490 & 1,000 & 1 \\
\hline water & 0,090 & 0,030 & 0,177 & $-0,140$ & $-0,206$ & 0,159 & $-0,057$ & 0,141 & $-0,013$ & 0,051 & $-0,011$ & $-0,031$ & $-0,471$ & 0,379 & $-0,092$ & $-0,317$ & 0,261 & 0,208 & 0,527 & $-0,247$ & 0,335 & 0,337 \\
\hline pH & $-0,041$ & $-0,057$ & 0,108 & $-0,056$ & 0,050 & $-0,069$ & 0,111 & 0,138 & 0,045 & $-0,003$ & 0,071 & 0,138 & $-0,201$ & 0,271 & $-0,447$ & $-0,350$ & 0,409 & 0,326 & 0,264 & 0,039 & 0,276 & 0,273 \\
\hline$c 1$ & 0,401 & 0,518 & 0,053 & 0,457 & 0,432 & $-0,339$ & 0,263 & 0,065 & 0,149 & 0,429 & 0,532 & 0,078 & 0,049 & $-0,026$ & $-0,033$ & $-0,010$ & $-0,004$ & 0,045 & $-0,042$ & 0,104 & 0,043 & 0,044 \\
\hline$c 2$ & 0,401 & 0,518 & $-0,018$ & 0,123 & 0,166 & $-0,357$ & $-0,123$ & $-0,452$ & 0,185 & $-0,098$ & $-0,233$ & $-0,018$ & 0,053 & $-0,071$ & 0,001 & 0,044 & $-0,049$ & $-0,010$ & $-0,029$ & 0,045 & 0,001 & $-0,002$ \\
\hline c3 & 0,401 & 0,518 & 0,219 & 0,013 & $-0,174$ & 0,295 & $-0,081$ & 0,502 & $-0,413$ & 0,269 & $-0,124$ & 0,035 & $-0,050$ & 0,001 & $-0,154$ & $-0,113$ & 0,184 & 0,079 & 0,072 & 0,009 & 0,050 & 0,050 \\
\hline c4 & 0,401 & 0,518 & $-0,002$ & $-0,384$ & $-0,522$ & 0,525 & $-0,012$ & $-0,070$ & 0,212 & $-0,475$ & $-0,068$ & $-0,243$ & 0,041 & $-0,080$ & 0,096 & 0,054 & $-0,033$ & $-0,055$ & $-0,192$ & $-0,125$ & $-0,247$ & $-0,249$ \\
\hline
\end{tabular}

variable codes

$\mathrm{xDD}$

yDD

$\mathrm{pH}$

\section{variable name and unity}

geographical coordinate $x$

geographical coordinate $y$

soil pH 


\begin{tabular}{|c|c|}
\hline water & water content in soil cores $(\mathrm{g})$ \\
\hline Clay & clay $(<2 \mu \mathrm{m})(\mathrm{g} / \mathrm{kg})$ \\
\hline Fi-Silt & fine silt $(2 / 20 \mu \mathrm{m})(\mathrm{g} / \mathrm{kg})$ \\
\hline Co- Silt & coarse silt $(20 / 50 \mu \mathrm{m})(\mathrm{g} / \mathrm{kg})$ \\
\hline Fi-Sand & fine sand $(50 / 200 \mu \mathrm{m})(\mathrm{g} / \mathrm{kg})$ \\
\hline Co-Sand & coarse sand $(200 / 2000 \mu \mathrm{m})$ \\
\hline $\mathrm{N}$ & Total Nitrogen $(\mathrm{g} / \mathrm{kg})$ \\
\hline $\mathrm{C} / \mathrm{N}$ & $\mathrm{C} / \mathrm{N}$ ratio \\
\hline Corg & Organic Carbon $(\mathrm{g} / \mathrm{kg})$ \\
\hline OM & Organic matter $(\mathrm{g} / \mathrm{kg})$ \\
\hline RDMC & Mean of Root Dry Matter content (mg.g-1) \\
\hline RGR & Mean of Relative Growth rate (mg.day-1) \\
\hline SRL & Mean Specific Root Length (m.g-1) \\
\hline RD & $\begin{array}{l}\text { Mean of Root Diameter }(\mathrm{mm}) \\
\text { Mean Green Area Index in December= ratio of leaf green area to ground } \\
\text { area }\end{array}$ \\
\hline GAIT6 & Mean of Green Area Index in April= ratio of leaf green area to ground area \\
\hline $\begin{array}{l}\text { Yellow Rust } \\
\text { Septoria }\end{array}$ & $\begin{array}{l}\text { Mean sensitivity to Yellow Rust (mean percentage of sporulating area) } \\
\text { Mean of sensitivity to Septoria leaf blotch (mean percentage of sporulating } \\
\text { area) }\end{array}$ \\
\hline
\end{tabular}


Table S4: Results of glm on the effect of the variety number (nbvar), composition of wheat variety assemblies (C1..) and soil parameters on the species richness of collembola (full model followed by final model, followed by Analysis of Deviance Table; intermediate model indicated that no interaction was significant)

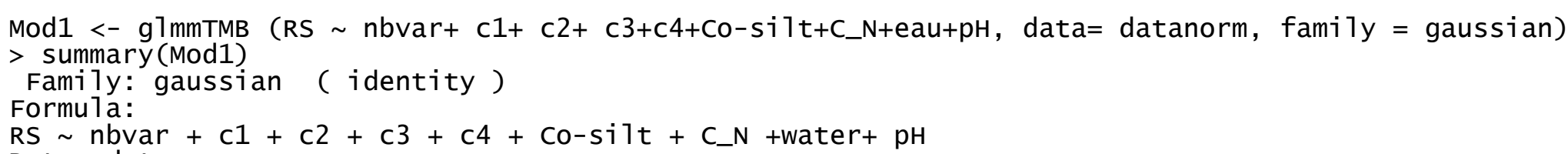




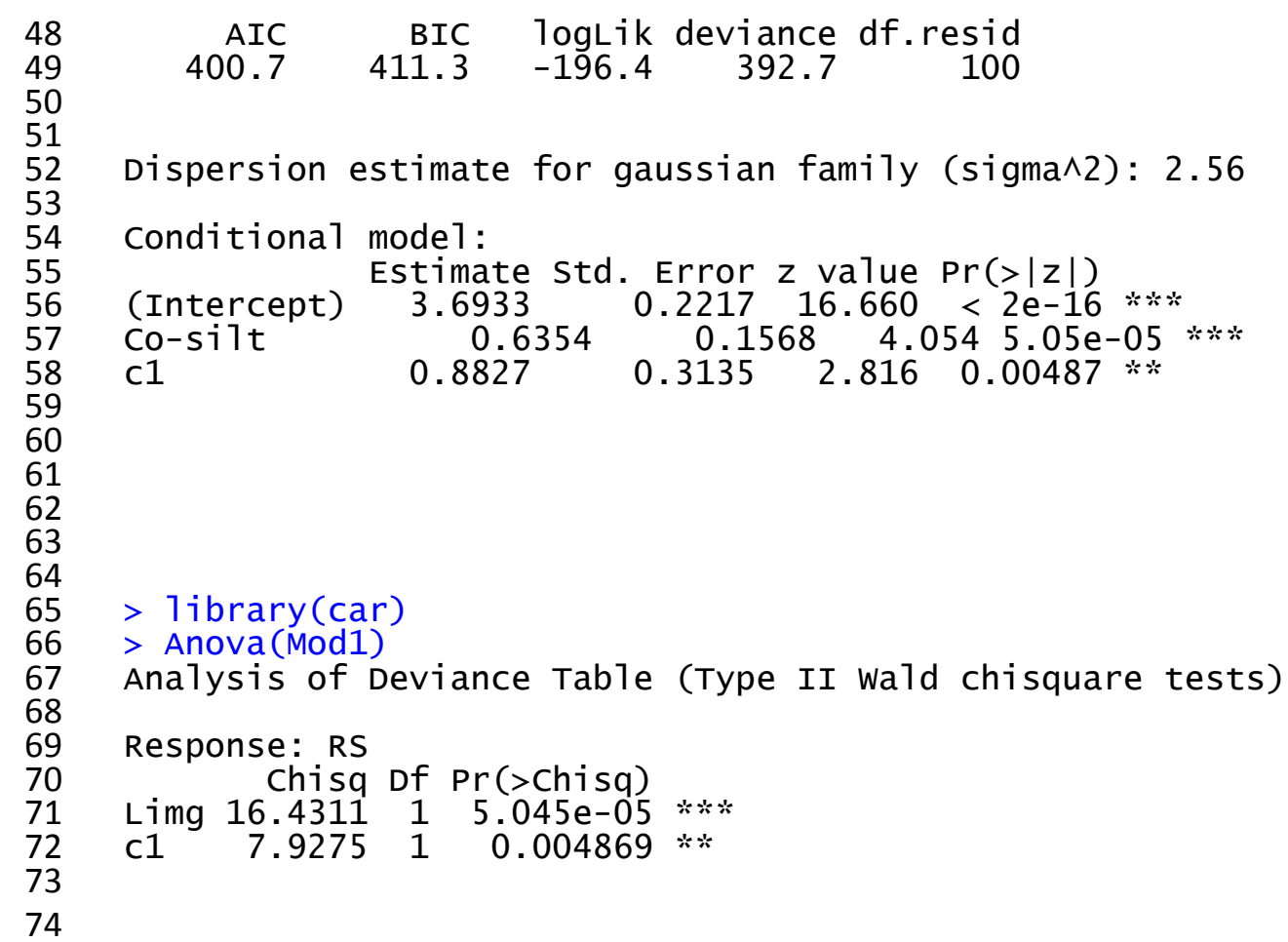


Table S5 : Results of glm on the effect of the functional group number of wheat (nbclu), wheat traits and soil parameters on the species richness interaction was significant)

Mod1 <- glmmTMB (RS nbclu+SRR+SRL+RD+GAIT1+GAIT6+YR+Septo+Co-si1t+C_N+eau+pH, data= datanorm, fami1y = gaussian) $>$ summary (Mod1)

Family: gaussian (identity)

Formula:

$\mathrm{RS} \sim \mathrm{nbClu}+\mathrm{SRR}+\mathrm{SRL}+\mathrm{RD}+\mathrm{GAIT1}+\mathrm{GAIT6}+\mathrm{YR}+\mathrm{Septo}+\mathrm{Co}-\mathrm{Si} 1 \mathrm{t}+$

C_N +water+ pH

Data: datanorm

$$
\begin{array}{rrrrr}
\text { AIC } & \text { BIC } & \text { logLik deviance df.resid } \\
409.3 & 446.3 & -190.7 & 381.3 & 90
\end{array}
$$

Dispersion estimate for gaussian family (sigma^2): 2.29

Conditional model:

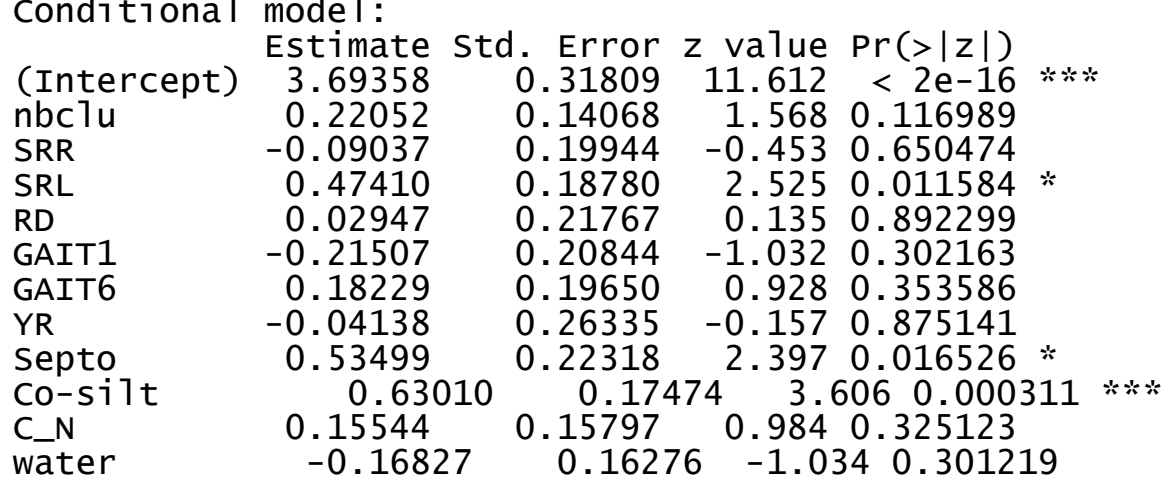


Mod1 <- g7mmTMB (RS SRL + Septo + Co-silt, data= datanorm, fami1y = gaussian) summary (Mod1)

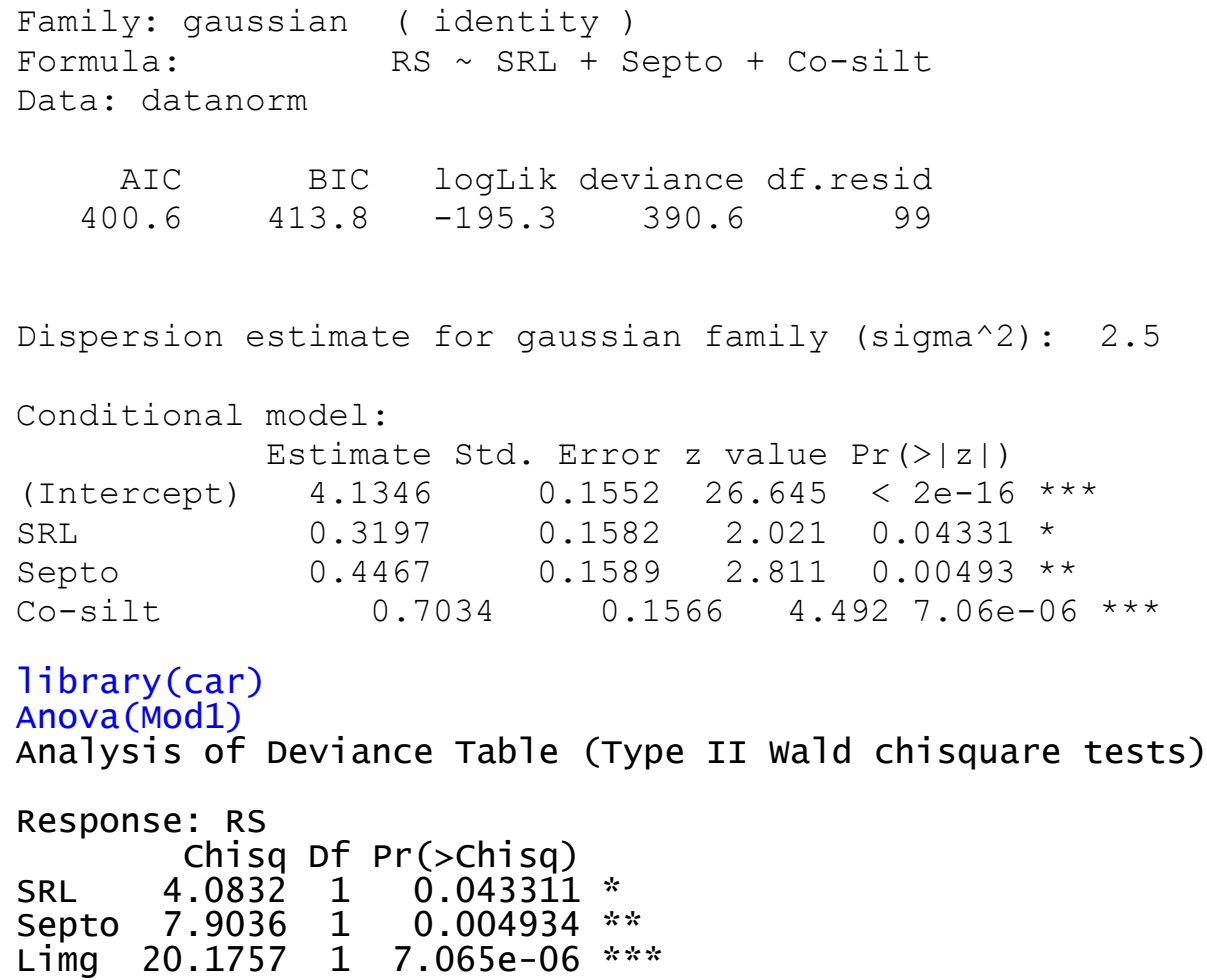


Table S6: Results of glm on the effect of the variety number (nbvar), composition of wheat variety assemblies (C1..) and soil parameters on the indicated that no interaction was significant)

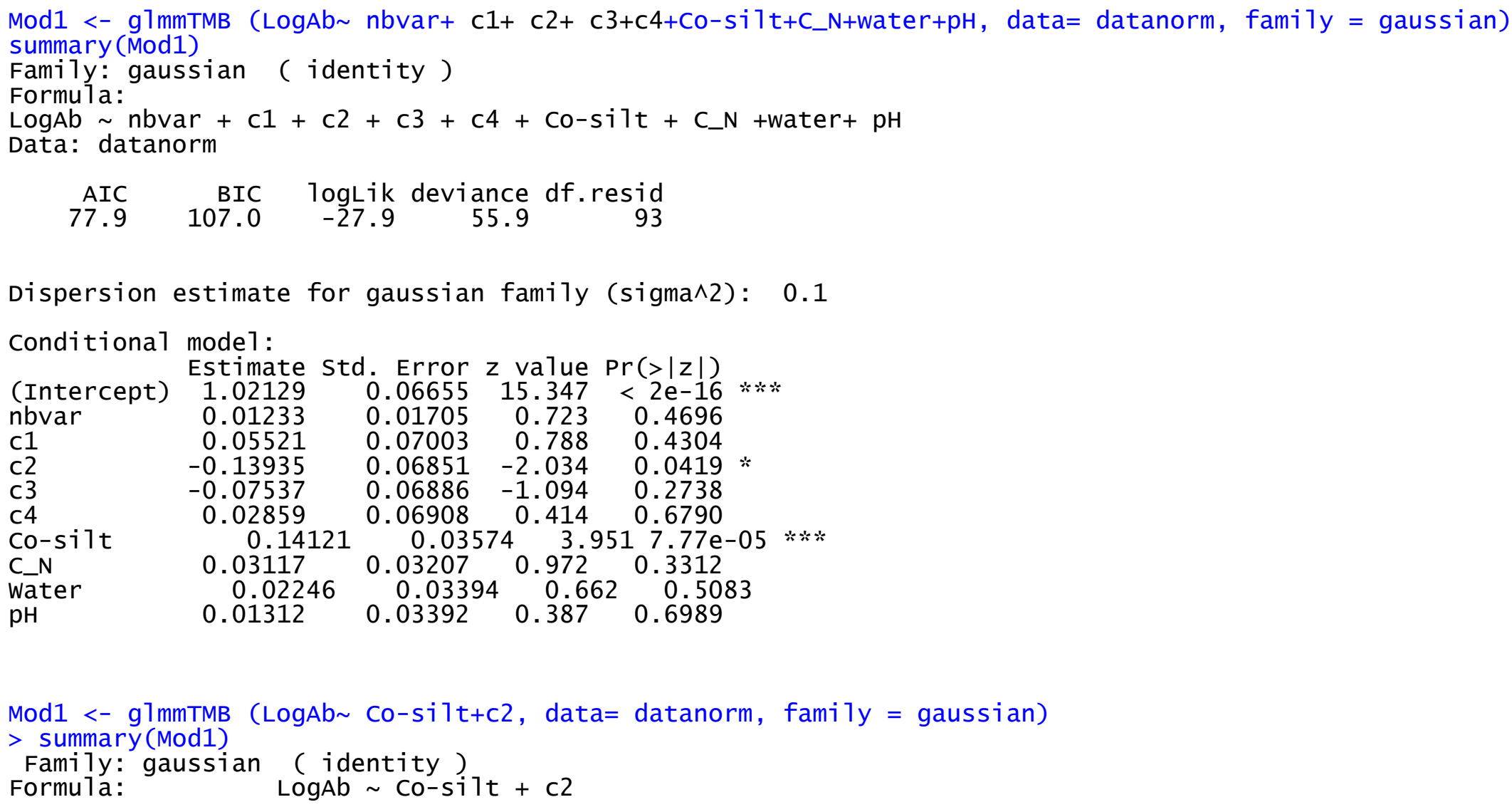


Data: datanorm

$\begin{array}{rrrr}\text { AIC } & \text { BIC } & \text { logLik deviance df.resid } \\ 68.4 & 79.0 & -30.2 & 60.4\end{array}$

Dispersion estimate for gaussian family (sigma^2): 0.105

Conditional mode1:

Estimate std. Error $z$ value $\operatorname{Pr}(>|z|)$

(Intercept) $1.05450 \quad 0.04490 \quad 23.485<2 \mathrm{e}-16 * * *$

$\begin{array}{lllll}\text { Co-silt } & 0.13164 & 0.03177 & 4.144 & 3.42 \mathrm{e}-05\end{array} * * *$ $\begin{array}{llll}c 2 & -0.11388^{17} & 0.06354^{-1.792^{144}} 0.0731\end{array}$

Anova (Mod1)

Analysis of Deviance Table (Type II wald chisquare tests)

Response: LogAb

$\begin{array}{rrr}\text { Chisq } & \text { Df } & \operatorname{Pr}(>\text { Chisq) } \\ \text { Limg } 17.1698 & 1 & 3.418 \mathrm{e}-05\end{array} * * *$

c2 3.2121 1 3.0 .07309 .

201 
Table S7 : Results of glm on the effect of the functional group number of wheat (nbclu), wheat traits and soil parameters on the Log of Collembola abundance (full model followed by final model, followed by Analysis of Deviance Table; intermediate model indicated that no interaction was significant)

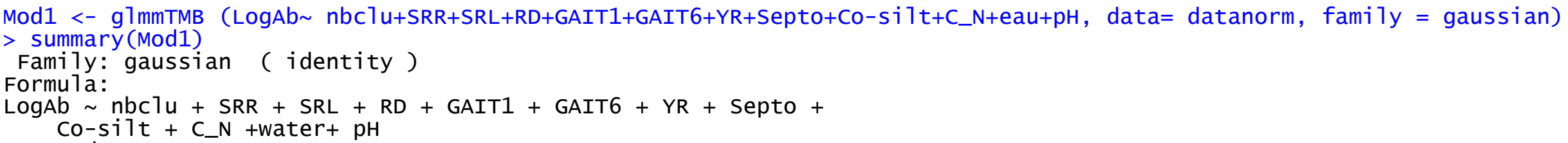


Mod1 <- g7mmTMB (LogAb Septo+Co-si1t, data= datanorm, family = gaussian) summary (Mod1)

Family: gaussian (identity)

Formula: LogAb $\sim$ Septo + co-silt

Data: datanorm

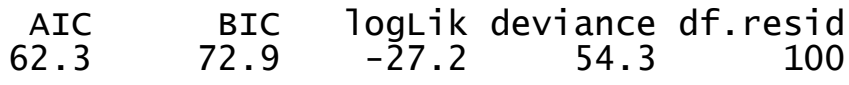

Dispersion estimate for gaussian family (sigma^2): 0.0987

Conditional mode1:

Estimate std. Error $z$ value $\operatorname{Pr}(>|z|)$

$\begin{array}{lrrrr}\text { (Intercept) } & 0.99756 & 0.03081 & 32.38 & <2 \mathrm{e}-16 * * * \\ & 0.09661 & 0.03099 & 3.12 & 0.00183 * *\end{array}$

$\begin{array}{lcccc}\text { Septo } & 0.09661 & 0.03099 & 3.12 & 0.00183 \\ \text { Co-si1t } & 0.13929 & 0.03099 & 4.49 & 6.98 \mathrm{e}-06\end{array} * * *$

\section{1ibrary (car)}

Anova (Mod1)

Analysis of Deviance Table (Type II wald chisquare tests)

Response: LogAb

septo $\quad 9.7172$ C $10.001826 * *$

co-si1t 20.1981 1 $6.982 \mathrm{e}-06 * * *$ 